\title{
A Geographic Information System (GIS)-based approach to adaptation to regional climate change: a case study of Okutama-machi, Tokyo, Japan
}

\author{
Yingjiu Bai • Ikuyo Kaneko • Hikaru Kobayashi • \\ Kazuo Kurihara • Izuru Takayabu • Hidetaka Sasaki • \\ Akihiko Murata
}

Received: 11 October 2012 / Accepted: 30 January 2013 / Published online: 19 February 2013

(C) The Author(s) 2013. This article is published with open access at Springerlink.com

\begin{abstract}
Recently, local governments have an increasing need to take extensive and effective local measures to adapt to regional climate change, but have difficulty knowing how and when to adapt to such change. This study aims: 1) to characterize an efficient and cost-effective database management tool (DMT) for developing a Geographic Information System (GIS) based approach to using observed and projected data, for decision-making by non-expert government authorities, and 2) to document how DMT can be used to provide specialized yet understandable climate change information to assist local decision-makers in clarifying regional priorities within a
\end{abstract}

Y. Bai $(\bowtie) \cdot$ I. Kaneko $\cdot$ H. Kobayashi

Graduate School of Media and Governance, Keio University, 5322 Endo, Fujisawa, Kanagawa 252-8520,

Japan

e-mail: bai@sfc.keio.ac.jp

I. Kaneko

e-mail: iccil@sfc.keio.ac.jp

H. Kobayashi

e-mail: hikaruko@sfc.keio.ac.jp

K. Kurihara $\cdot$ I. Takayabu $\cdot$ H. Sasaki $\cdot$ A. Murata

Meteorological Research Institute, 1-1 Nagamine, Tsukuba-city, Ibaraki 305-0052, Japan

K. Kurihara

e-mail: kkurihar@mri-jma.go.jp

I. Takayabu

e-mail: takayabu@mri-jma.go.jp

H. Sasaki

e-mail: hsasaki@mri-jma.go.jp

A. Murata

e-mail: amurata@mri-jma.go.jp 
wide array of adaptation options. The DMT combines climate change mapping, statistical GIS, and a vulnerability assessment. Okutama-machi, a $225.63 \mathrm{~km}^{2}$ sparsely populated mountainous region (2012 population 5,856) northwest of Tokyo, Japan, was chosen for this pilot study. In this paper, the most recent regional climate projections ( $5 \mathrm{~km}$ resolution) are transcribed into an understandable form for use by non-expert citizens who use the GIS-based DMT. Results illustrate qualitative agreement in projection of summer daily mean temperatures; the mean temperature increase at Okutama-machi is the greatest of any area in Tokyo. In comparing near future and future conditions, August monthly mean temperature will increase more than $0.7-0.9^{\circ} \mathrm{C}$ and $2.8-2.9{ }^{\circ} \mathrm{C}$, and monthly precipitation by $50 \%$ and $25-41 \%$, respectively. However, the root mean square (RMS) errors and bias of percentage change for monthly precipitation in summertime are $26.8 \%$ and $4.3 \%$, respectively. These data provide an early warning and have implications for local climate policy response.

Keywords Climate change projection · Database management system (DMS) - Geographic information system (GIS) · Local government decision-making · Okutama-machi · Regional climate change

\section{Introduction}

Observational records clearly indicate mean global temperatures have increased by about $0.74{ }^{\circ} \mathrm{C}\left(0.56{ }^{\circ} \mathrm{C}-0.92{ }^{\circ} \mathrm{C}\right)$ in a linear fashion from 1906 to 2005 . The linear warming trend over the last 50 years $\left(0.10{ }^{\circ} \mathrm{C}-0.16{ }^{\circ} \mathrm{C}\right.$, or an average of $0.13{ }^{\circ} \mathrm{C}$, per decade) is nearly twice that of the last 100 years (IPCC 2007a). These increases are associated with greater increases in daily minimum temperatures than of maxima, leading to a reduction in the diurnal temperature range. In a future warmer climate with higher mean temperature, extreme summer temperatures around the world would continue to increase (Duffy and Tebaldi 2012; Elguindi et al. 2012; Kusaka et al. 2012; Easterling et al. 2000). Also, the United Nations Intergovernmental Panel on Climate Change (IPCC) Special Report on Emission Scenarios (SRES) A1B scenario suggests that by the mid-2090s, global sea levels will reach $0.22-0.44 \mathrm{~m}$ above 1990 levels, and sea levels are expected to rise at about $4 \mathrm{~mm} \mathrm{yr}^{-1}$. Sea level rise during the 21 st century is projected to have substantial geographical variability. Hydrographic observations (IPCC 2007b) also suggest substantial spatial variation in rates of sea level change will occur. Recently, the Earth System Models (EMS) used in the last IPCC report project a total global sea-level rise of $20-60 \mathrm{~cm}$ by 2100 . Also, complex regional patterns will lead to a larger rise in some regions and to considerable but poorly quantified inter-annual and decadal variability of sea level change (Willis and Church 2012). For a local study, if resources are available, an impact assessment could consist of local socio-economic scenarios and downscaled/processed sea-level data combined with a surge model and vertical land movement observations. The magnitudes of the potential impacts associated with high sea-level rise scenarios are of sufficient concern to merit consideration in impact, vulnerability and adaptation studies (IPCC Data Distribution Centre 2011) because many Asian-megacities are built on deltas, such as metro Manila (Philippines), Jakarta (Indonesia) and Bangkok (Thailand). However, since impact assessments are commonly based on elevation data, the need for sea-level change scenarios as part of impact and adaptation assessments should be considered. 
Adaptation to climate change is largely time and scale dependent and this dependence is a function of both climate impacts on particular activities and its adaptive potential (Jones 2000). After the 2003 European heat wave, climatologists, medical specialists, and social scientists expedited efforts to revise the European vulnerability assessment system and integrated risk governance frameworks for climate change adaptation (Schröter et al. 2004; Lass et al. 2011). All studies indicate that a capability for climate prediction at regional and local scales is vital to aid in identifying possible adaptation strategies. In Europe, activities are already underway to explore the benefits of increased regional climate model (RCM) resolution (a $10 \mathrm{~km}$ resolution or less) for simulating observed regional climate processes (World Climate Research Programme (WCRP) Coupled Model Intercomparison ProjectPhase 5: Special Issue of the Climate Variability and Predictability (CLIVAR) Exchanges Newsletter 2011). This creates new demands on researchers. Developing and applying an advanced observational database and using the output of RCMs under Coupled Model Intercomparison Project-Phase 5 (CMIP5) as efficiently as possible is both essential and necessary, not only for climate scientists, but also for the growing number of stakeholders, policy-makers and the enlightened public. Based on advice given by Overpeck et al. (2011), "a new paradigm of more open, userfriendly data access is needed to ensure that society can reduce vulnerability to climate variability and change, while at the same time exploiting opportunities that will occur."

The scientific questions that arose in the IPCC Fourth Assessment Report (AR4) will need to be addressed through CMIP5 in time for evaluation in the Fifth Assessment Report (AR5) scheduled for publication in late 2013. Currently, the CMIP5 model's output is freely available to researchers through a gateway linked to modeling and data centers or the main CMIP5 Data Portals (see Box1) worldwide, where the data are archived. Climate modeling data is stored in huge and complex digital repositories. The CMIP5 can modulate large-scale climate databases on regional to local scales, with a new set of so-called community-led Reference Concentration Pathways (RCPs which process scenarios for IPCC AR5, see Box2) that provide future estimates of greenhouse gas (GHG) concentrations. Expert knowledge, including data sources or RCPs, is a particularly useful resource for research; however, it is not in an understandable form for non-expert citizens. A basic tool to support decision-making by non-expert government employees and politicians seems necessary, which would enable exchanges of high-quality climatic data and information about the science of climate change in understandable forms available to non-expert citizens which would fit with a new resilient approach for local policymakers to meet the regional demands.

Box 1 CMIP5 models output is freely available to researchers

All of the CMIP5 model output can now be accessed through any one of the following

ESGF (Earth System Grid Federation < http://esgf.org/ >) gateways:

Program for Climate Model Diagnosis and Intercomparison (PCMDI): http://pcmdi9.1lnl.gov/

British Atmospheric Data Centre (BADC): http://esgf-index1.ceda.ac.uk

Deutsches Klimarechenzentrum; German Climate Computing Centre (DKRZ): http://esgf-data.dkrz.de

National Computational Infrastructure (NCI): http://esg2.nci.org.au

Source: CMIP5 Coupled Model Intercomparison Project: CMIP5 -Data Access- Availability. http://cmippcmdi.llnl.gov/cmip5/availability.html. 
Box 2 Information on individual RCPs

Four RCPs are produced. Information about the RCPs and the scenario development process for the IPCC AR5 can be found in the IPCC Expert Meeting Report on New Scenarios and Moss et al. (2010). http://www.aimes.ucar.edu/docs/IPCC.meetingreport.final.pdf http://www.nature.com/nature/journal/v463/n7282/pdf/nature08823.pdf

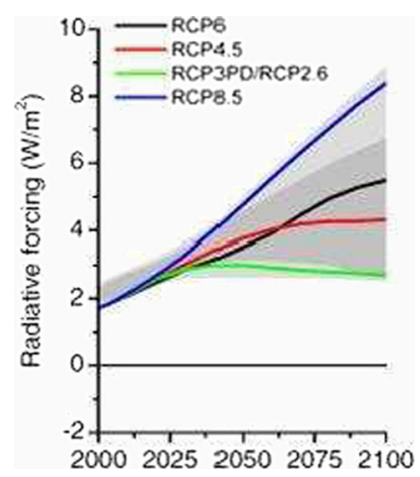

RCP8.5: Rising radiative forcing pathway leading to $8.5 \mathrm{~W} / \mathrm{m} 2$ in 2100 .

RCP6: Stabilization without overshoot pathway to $6 \mathrm{~W} / \mathrm{m} 2$ at stabilization after 2100 .

RCP4.5: Stabilization without overshoot pathway to $4.5 \mathrm{~W} / \mathrm{m} 2$ at stabilization after 2100 .

$\mathrm{RCP}$ 2.6: Peak in radiative forcing at $\sim 3 \mathrm{~W} / \mathrm{m} 2$ before 2100 and decline.

Source: IPCC Data Distribution Centre (2012c) Scenarios Process for AR5. http://sedac.ciesin.columbia.edu/ddc/ar5_scenario_process/RCPs.html

Mounting evidence exists related to the need for basic tools to support local scientificpolicy dialogue as part of local decision-making processes for adaptation planning at the local scale (Hallegatte and Corfee-Morlot 2011). In particular, Jones (2000) recommended that the uncertainty which exists within projections of regional climate can be managed where it is unquantifiable. Tools are vital in analyzing and managing the uncertainty which accompanies climate change assessments. Corfee-Morlot et al. (2011) also indicated, institutional design with inclusion of analytic-deliberative practices, focusing on the potentially key tool of characterizing projection uncertainty, facilitates good decision-making. However, the basic tools for local government leaders are particularly lacking. If user-friendly software packages for using these increasing numbers of data sources from observations and RCM simulations were provided, that would aid in identifying possible adaptation strategies and managing uncertainty in climate change projections effectively.

The objective of this paper is to provide a cost-effective, user-friendly database management tool (DMT) for decision-making by local governments, using observed and projected data. The Climatic Research Unit (IPCC Data Distribution Centre 2012a) has a free, high-resolution dataset. This dataset is available in NetCDF and GeoTIFF formats, which are both GIS (geographic information system) compatible. Recently, GIS has been increasingly used at all levels of government, in both developed and developing countries. We used high-quality daily data from the Japan Meteorological Agency (JMA), which are available to local governments (Japan Meteorological Agency 2012a). To take into account local priorities and issues, projections were from a $5 \mathrm{~km}$-mesh, non-hydrostatic, cloud system-resolving regional climate model Non-Hydrostatic Regional Climate Model (NHRCM)-5 km, $5 \mathrm{~km}$ resolution), following the Special Report on Emissions Scenarios (SRES) A1B scenario. Those were dynamically downscaled results from the Meteorological Research Institute (MRI)-AGCM3.2S (IPCC Data Distribution Centre 2012b). The MRI-AGCM3.2S is an Atmospheric General Circulation 
Model for AMIP (Atmospheric Model Intercomparison Project) conducted under Coupled Model Intercomparison Project-Phase 5 (CMIP5 2012).

We developed the basic DMT with three GIS modules that can freely and easily produce a wide variety of data or maps, plus warning information, available in a GIS domain. In this paper, two major challenges for climate science revolving around data have been addressed. One is ensuring that the highest resolution projected climate change data $(5 \mathrm{~km}$ resolution) become easier and cost-effective so that up-to-date information can be put into widespread use by a GIS-based DMT. Second is making sure these data and the results that depend on them are useful to and understandable by a broad interdisciplinary audience, especially by the local policy-makers. A similar approach can be achieved in both developed countries and developing countries using the GIS-based DMT. These would improve routine decision-making and clarify regional priorities and issues effectively around the world. All GIS mapping output can be formatted into a Keyhole Markup Language (KML)/Keyhole Markup Language Zip (KMZ) file that can be readily used and displayed by Google Earth or other Earth browser programs. These greatly benefit local governments in undeveloped areas and depopulated regions, for obtaining information via the world wide web (WWW).

To describe the methodological steps in the DMT with GIS modules, Okutama-machi in Tokyo, Japan was chosen for a pilot study ("machi" means town in Japanese). It is a relatively unpopulated region to the northwest of the city of Tokyo (area $225.63 \mathrm{~km}^{2}$; population 5,856 as of 1 January 2012), with the highest peak $(2,017 \mathrm{~m})$ in the Tokyo metropolitan area. This paper describes the basic DMT with four GIS modules and sources of projected daily data in "Data and Methods". In "Pilot Study of Okutamamachi, Tokyo", the case study of Okutama-machi is used to explain how to examine vulnerability and investigate adaptation to regional climate change through the DMT by local decision-makers. "Pilot Study of Okutama-machi, Tokyo" presents results from Okutama-machi and projected data quality.

\section{Data and methods}

\subsection{Free international daily datasets at national levels in a digital format}

As mentioned above, free international daily datasets including data applicable at national levels in digital form have been improved worldwide (Alexander et al. 2006) and these datasets include climate observations and climate models, have worldwide open-access, and are updated by IPCC Data Distribution Centre (http://ww.ipccdata.orgobs/index.html). Also, a number of new results have been published; RCMs can resolve features down to $50 \mathrm{~km}$ or less and many regional high-resolution (about $25 \mathrm{~km}$ ) projections of future climate change have been developed (Hayhoe et al. 2008; Elguindi and Grundstein 2012; Patricola and Cook 2010). The Earth System Grid Federation (ESGF) is a coordinated international collaboration of individuals and institutions that is developing, deploying and maintaining software infrastructure for the management of model output and observational data. Researchers worldwide can now access ESGF data holdings through any of the gateways hosted by ESGF partners, including laboratories in the U.S. funded by the Department of Energy (DOE), the National Science Foundation (NSF), the National Aeronautics and Space Administration (NASA), and the National Oceanic and Atmospheric Administration (NOAA), and at laboratories elsewhere, including the Australian National University (ANU) National Computational Infrastructure (NCI), the British Atmospheric Data Center 
(BADC), the Max Planck Institute for Meteorology of the German Climate Computing Centre (DKRZ). Users can access all data sets freely using web browsers (ESGF gateways $<$ http://esgf.org/> or ESGF data nodes $<$ http://www-pcmdi.llnl.gov/>).

In this study, we used a high-quality daily dataset from the JMA Observations (Surface observations http://www.jma.go.jp/jma/en/Activities/observations.html) and projections ( $5 \mathrm{~km}$ resolution) from the NHRCM-5 km following the SRES-A1B scenario developed by the Meteorological Research Institute (MRI), JMA supported by Innovative Program of Climate Change Projection for the 21st Century (KAKUSHIN Program). The NHRCM-5 km is a dynamic downscaling of results from MRI-AGCM3.2S (20 km resolution) under CMIP5 (the MRI-AGCM3.2S output can be downloaded from CMIP5 or the IPCC Data Distribution Centre webpage). Also, we re-produced the GIS statistics conducted stepwise for local governments by the Ministry of International Affairs and Communications, Japan (Statistics Bureau: Database of the national census) using the basic DMT.

\subsection{Methods}

This study had two main components: developing a cost-effective, user-friendly DMT for local decision-making and an empirical pilot study of regional adaptation measures designed for using the DMT. Figure 1 outlines the procedures adopted here and depicts the DMT with three GIS modules. The DMT is a mapping tool for managing an integrated spatial and attribute database, with a suite of climate change indices, regional statistics and regional vulnerability indices focused on extreme climatic events. An existing DMT was built using three different GIS modules consisting of spatial map layers with their spatial and attribute databases. These three modules are climate change mapping (climate change information with geographic scale and location information), regional statistical GIS, and vulnerability assessment by GIS.

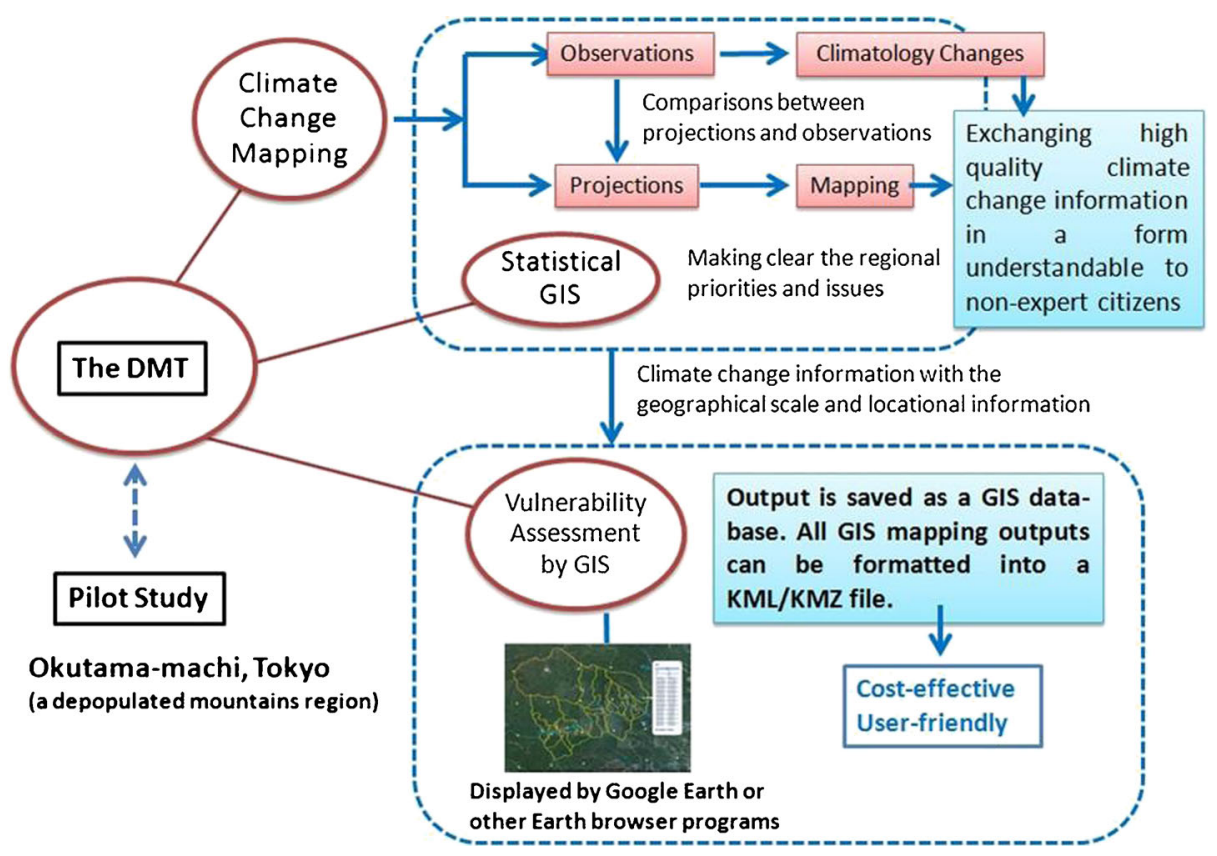

Fig. 1 Diagram of procedures adopted in this study 
Vulnerability assessment by GIS includes natural, social and economic vulnerabilities, which are intended to inform decision-makers by analyzing current and potential impacts of global change and by recognizing pressures from other stresses. All data is computed and analyzed for regional tasks in the GIS domain, and output is saved as a GIS database. Moreover, the user can easily transform all output into a KML/KMZ file, which is available for presentation using freely available tools (e.g., Google Earth) and an internet connection.

The DMT mapping presents observed (station data) and projected (grid mesh data) data together easily, using GIS (Fig. 1). Mapping the observed and projected data on the same GIS domain can allow the user to directly link other GIS data, such as societal and biological impacts and climate change. Using DMT for climate-change mapping is a vehicle for readily depicting special distribution changes and trends across temporal and geographic scales. The output is available for presentation on Google Earth by the DMT, as needed.

\subsubsection{Climate change mapping}

Data quality and homogeneity is important to decision-making using the basic DMT. We used a high-quality daily dataset from the JMA, and projections from the NHRCM-5 km following an SRES-A1B scenario. The MRI-AGCM3.2S supported by KAKUSHIN Project, is used as initial and lateral boundary conditions (Kitoh et al. 2009; Sasaki et al. 2012; Nakano et al. 2012). MRI-AGCM3.2S output is successful in simulating characteristic features of the seasonal cycle of the East Asian summer monsoon and topographyregulated precipitation data has good agreement with observations (Mizuta et al. 2012). Several recent empirical studies have applied NHRCM-5 km output to date for months from June to October. For instance, research has been conducted related to summertime temperature extremes and daily precipitation across Japan in the late 21 st century using the NHRCM-5 km (Murata et al. 2012; Kanada et al. 2010). These studies indicate that the NHRCM-5 km significantly improves the reproduction of the present climate. In particular, the bias of models with observations for daily mean temperatures in June, July, August, September and October was within $0.5 \mathrm{~K}$ (700 samples covering Japan) for the present climate (Murata et al. 2012; Nakano et al. 2012). Thus, we used only NHRCM-5 km output data for summertime (July to October data).

\subsubsection{GIS statistics}

Statistics often inform policy development. As Davidian and Louis (2012) stated, statistics is the science of learning from data, and of measuring, controlling, and communicating uncertainty; it thereby provides essential navigation for controlling the course of scientific and societal advances. GIS statistics of the DMT represents a mapping approach designed to present a regional development snapshot of governmental statistics information. Mapping observed and projected data on the same GIS domain, using a common database that includes environmental and socioeconomic statistics, can be an effective and easy method to analyze and solve a particular problem. Also, multiple potential impacts on multiple sectors can be projected. These potential impacts combine with low adaptive capacity, based on a socioeconomic regional scale generic index.

After the 1990s, GIS statistical analysis was conducted stepwise for local governments in Japan. Datasets from GIS statistics are available for re-editing and visualization on Google Earth, as needed. 


\subsubsection{Vulnerability assessment by GIS}

The IPCC Third Assessment Report "Climate Change 2001" (2003) clearly stated vulnerability to climate change is determined by two sets of factors; one external to the system, and the other internal. External factors consist of the character, magnitude, and rate of climate change, and variation to which the system is exposed. Internal factors are the sensitivity and adaptive capacity of the system itself. Unfortunately, empirical and theoretical evidence of how potential impacts and adaptive capacity can be combined into vulnerability measures is very limited. Here, we create environmental and socioeconomic statistics and then combine them with climate change observations and GIS projections. The resulting maps are useful in illustrating vulnerability in terms of negative potential impacts and limited adaptive capacity. All results are made available to stakeholders in the form of a digital atlas of potential impacts, adaptive capacity and dimension of vulnerability.

\section{Pilot study of Okutama-machi, Tokyo}

The following is an illustrative example of adaptation to regional climate change for decision-making by a local government, using the DMT. For a pilot study, we chose an unpopulated mountainous region accessible 2 hours northwest of Tokyo by train or car (Okutama-machi; Fig. 2). Lake Okutama (Fig. 3b), an impounded lake which feeds the Tama River which can hold 185 million $\mathrm{m}^{3}$ of water, supplies approximately $20 \%$ of Tokyo's water supply.

Tokyo is a megacity with a population of 13.18 million as of 1 January 2012, and covers an area of 2,187.5 $\mathrm{km}^{2}$ (Ministry of International Affairs and Communications 2012). The number of people aged 65 or older in Tokyo is 2.64 million, or $20.4 \%$ of the total population, which includes $9.0 \%$ of the total population of the elderly in Japan; nationwide, the number of elderly people reached a record 29.25 million, or $23.01 \%$ of the total population of 128.06 million, as of 1 October 2010). Similar to megacities in other developed countries, municipalities with aging populations are expected to suffer greatly from climate change and are vulnerable to global change because only a few people have sufficient information on which to base action. The continuing increase in size of the elderly population is an urgent issue for metropolitan governments. For example, Tokyo will become an ageing-megacity with the projected percentage of elderly people exceeding $25 \%$ by 2030 (Ministry of International Affairs and Communications 2012). Meanwhile, in Tokyo, the population has continued to increase in the inner city (Table 1). From 2005 to 2010 , the population grew by 456,042 people, with a growth rate between $12.8 \%-24.8 \%$ (Ministry of International Affairs and Communications 2012). The concentration of population within the inner-city area has been a serious problem in the city.

On the contrary, as population and infrastructure became concentrated in the inner city of Tokyo, two surrounding localities (Okutama-machi and Hinohara Village; Fig. 2) have been depopulated.

Okutama-machi, in the extreme western part of Tokyo, has seen its population continuously decline since 1955, combined with a rising average age (Fig. 3a). As of 1 October 2010 only 6,045 people live in Okutama-machi (Ministry of International Affairs and Communications 2012; Table 1). Figure 2 shows Okutama-machi has poor transportation facilities creating a wide gap between the services available in this small town and the innercity area; the lack of good transportation limits employment opportunities as well as limits access to medical and public aid services (Fig. 3b). These factors have contributed to the 
a
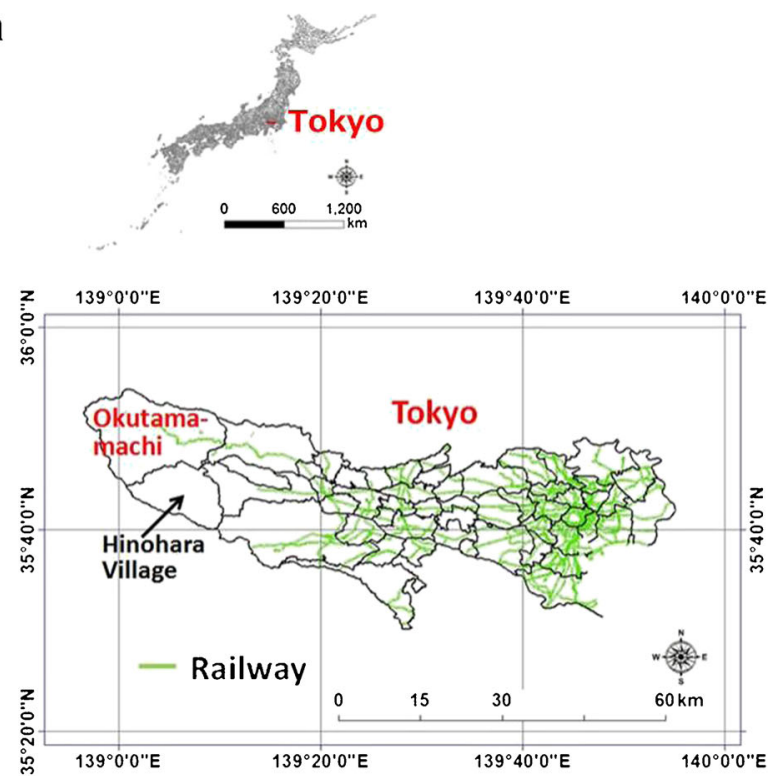

b
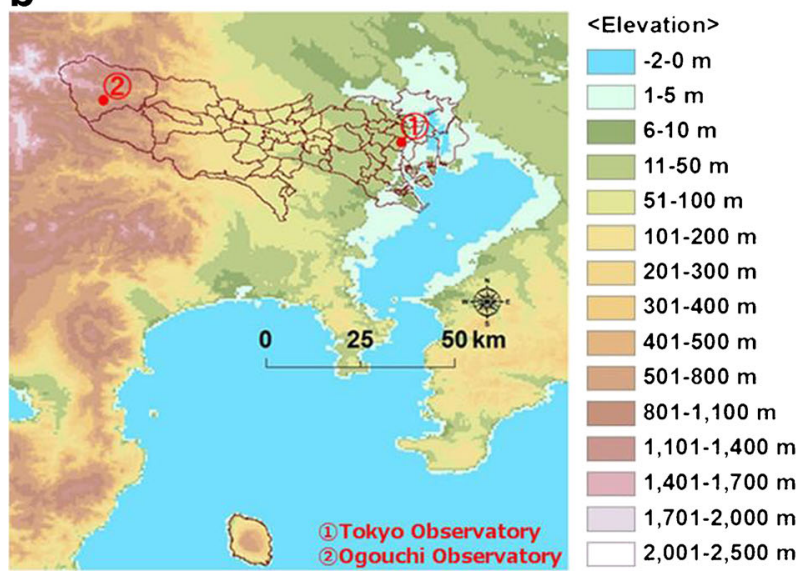

Fig. 2 Locations and transportation network in Okutama-machi (a), and elevations (b) of observatories at Okutama-machi and Tokyo city center. Tokyo Station $\left(35^{\circ} 41.1^{\prime} \mathrm{N}, 139^{\circ} 45.6^{\prime} \mathrm{E}\right.$; elevation, $\left.6.1 \mathrm{~m} \mathrm{AMSL}\right)$; Ogouchi Station $\left(35^{\circ} 47.5^{\prime} \mathrm{N}, 139^{\circ} 0.3^{\prime} \mathrm{E}\right.$; elevation, $530.0 \mathrm{~m}$ AMSL). Figure produced by: Yingjiu Bai. Data Source: Japan Meteorological Agency 2012b

rapid decline in population, which together with the aging general population and workforce, cause various changes in regional socioeconomic structure. According to the latest national census (Ministry of International Affairs and Communications 2012), the number of people aged 65 or older in Okutama-machi is 2,498 , or $41.3 \%$ of the total population; significantly $15.9 \%$ of these elderly people live alone (Table 1). Okutama-machi low population level makes it a distinctive region within Japan. Populations, community life and land-use in the Tokyo's inner-city area and unpopulated regions vary widely in these attributes across the landscape, so the ability of people to adapt to changing climates in the metropolitan area is unevenly distributed. 

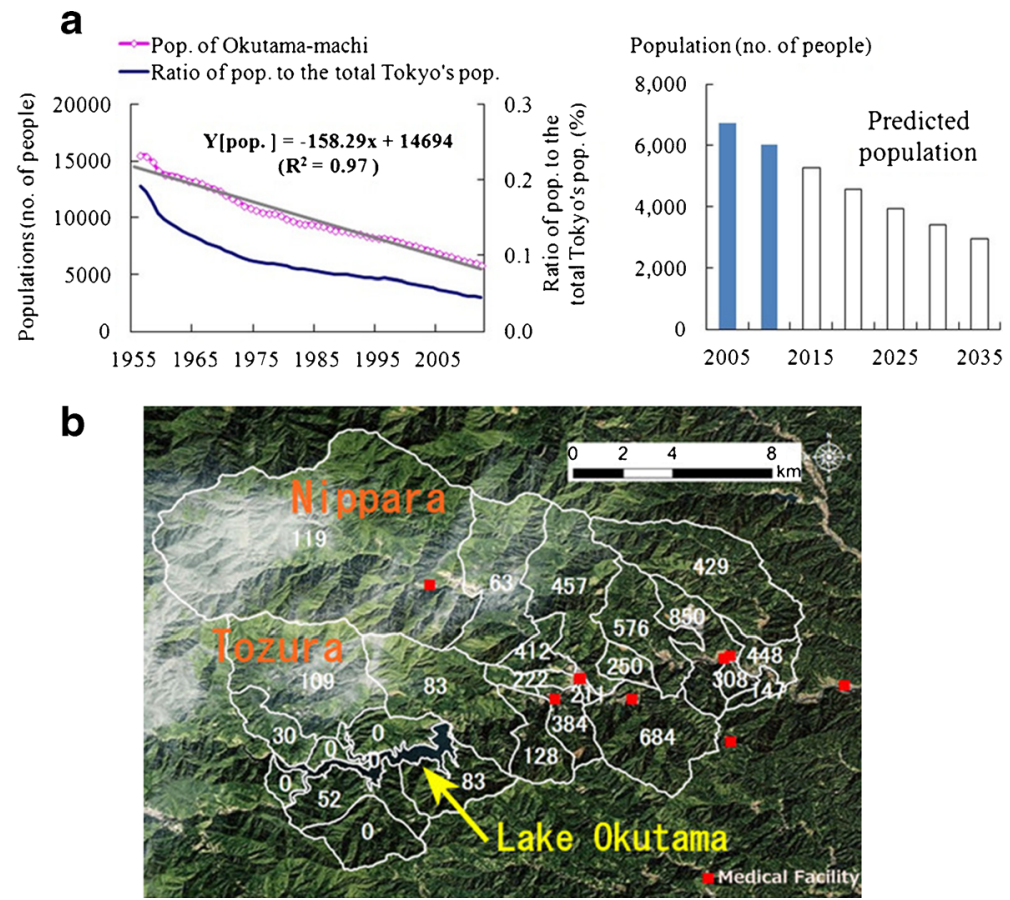

Fig. 3 Population decrease from 1955 to 2012 and the predicted population during 2015-2035 (a); medical facilities location map presented in Google Earth (b red color points) in Okutama-machi. Numbers b indicate the population. Figure produced by: Yingjiu Bai. Data Source: Ministry of International Affairs and Communications 2012

Recent studies indicate global warming will be more marked at the mega-city scale, because of processes such as the creation of urban heat islands (Lemonsu et al. 2013). Figure 4a shows that annual mean temperature in Tokyo has risen about $3{ }^{\circ} \mathrm{C}$ over the past century, based on long-term observational data from the meteorological station in central Tokyo (Fig. 2b, (1) (indicates the Tokyo station): $35^{\circ} 41.1^{\prime} \mathrm{N}, 139^{\circ} 45.6^{\prime} \mathrm{E}$, elevation $6.1 \mathrm{~m}$ above mean sea level (abbreviated as AMSL)). Okutama-machi has only one automatic observation station, named Ogouchi, because the area has few residents and is in a mountainous location with limited transportation facilities (Fig. 2b, (2) (indicates the Ogouchi station): $35^{\circ} 47.5^{\prime} \mathrm{N}, 139^{\circ} 0.3^{\prime} \mathrm{E}$, elevation $530.0 \mathrm{~m}$ AMSL). Table 2 and Fig. 4 show the climates of Tokyo and Ogouchi stations are warming based on changes in daily maximum

Table 1 Comparison of population in the Tokyo metropolitan area and Okutama-machi (a sparsely populated mountainous region)

\begin{tabular}{llllllll}
\hline & $\begin{array}{l}\text { Area } \\
\left(\mathrm{km}^{2}\right)\end{array}$ & $\begin{array}{l}\text { Population } \\
\text { (person) }\end{array}$ & $\begin{array}{l}\text { Pop. density } \\
\left(\text { per./km } \mathrm{km}^{2}\right)\end{array}$ & $\begin{array}{l}\text { Pop. growth } \\
\text { rate: 2005- } \\
2010\end{array}$ & $\begin{array}{l}\text { Population } \\
\text { aging (person)/ } \\
\text { rate }\end{array}$ & $\begin{array}{l}\text { Number of } \\
\text { households }\end{array}$ & $\begin{array}{l}\text { Number of single- } \\
\text { elderly person } \\
\text { household (ratio) }\end{array}$ \\
\hline Tokyo metropolitan & $2,187.50$ & $13,159,388$ & $6,015.7$ & $4.6 \%$ & $\begin{array}{c}2,642,231 \\
(20.4 \%)\end{array}$ & $6,393,768$ & $622,326(9.7 \%)$ \\
Okutama-machi & 225.63 & 6,045 & 26.8 & $-10.3 \%$ & $2,498(41.3 \%)$ & 2,217 & $353(15.9 \%)$ \\
\hline
\end{tabular}

Ministry of International Affairs and Communications 2012 

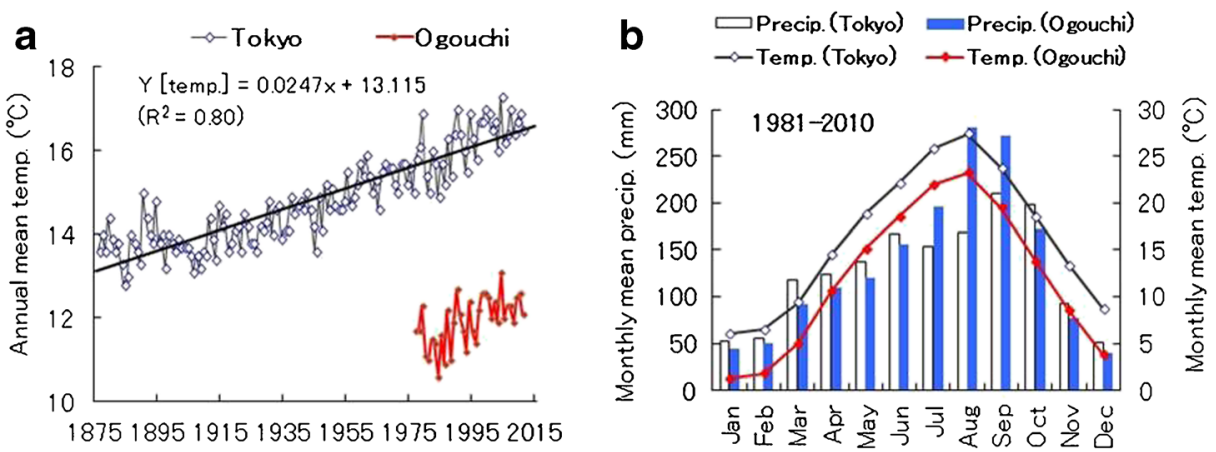

Fig. 4 Annual mean temperature increase (a), and observed trends of monthly mean precipitation and temperature during 1981-2010 (b) in the Tokyo metropolitan area, based on average records from Tokyo (city center) and Ogouchi stations (rural area). Upper straight line in (a) denotes estimated trend of annual mean temperature increase for Tokyo station; slope $=0.0247^{\circ} \mathrm{C} /$ year, $\mathrm{R}^{2}=0.80$. Tokyo Station $\left(35^{\circ} 41.1^{\prime} \mathrm{N}\right.$, $139^{\circ} 45.6^{\prime} \mathrm{E}$; elevation, 6.1 m AMSL); Ogouchi Station $\left(35^{\circ} 47.5^{\prime} \mathrm{N}, 139^{\circ} 0.3^{\prime} \mathrm{E}\right.$; elevation, $530.0 \mathrm{~m}$ AMSL. Data Source: Japan Meteorological Agency 2012b

temperature $\left(\mathrm{T}_{\max }\right)$ and minimum temperature $\left(\mathrm{T}_{\min }\right)$ records, although the annual mean temperatures and monthly mean temperatures at Ogouchi are more than $4{ }^{\circ} \mathrm{C}$ colder than those of Tokyo.

Figure 5(a) indicates the number of people hospitalized with heat stroke from 2000 to 2011 in Tokyo. In summer 2010, the monthly maximum temperature in August in Tokyo reached $29.6{ }^{\circ} \mathrm{C}$. More than 70 days (or 10 days) had extremely high monthly maximum temperatures exceeding $30{ }^{\circ} \mathrm{C}$ (or $35{ }^{\circ} \mathrm{C}$ ) during the entire summer (Fig. 5c). This heat resulted in 272 deaths and about 4,700 hospitalizations for patients with heat stroke (Fig. 5b). In summer 2011, about 3,900 people were hospitalized with heat stroke (Fig. 5a), even though the August maximum temperature was $27.5^{\circ} \mathrm{C}$, because the temperature difference between monthly maximum temperatures in June and July much higher than normal by $4.5{ }^{\circ} \mathrm{C}$ (Fig. 5b). In addition, after the March 2011 disaster, power generation in the greater Tokyo area decreased by $20 \%$, so that government-ordered power-saving efforts in eastern and northeastern Japan also had been requested in 2011.

Even though August maximum temperatures in 2005 and 2007 were higher than 2011, fewer people were hospitalized with heat stroke, because the temperature differences between monthly maximum temperatures in June and July were lower by $2.4{ }^{\circ} \mathrm{C}$

Table 2 Comparison of climatological changes in the Tokyo metropolitan area, based on annual normal climatological records of Tokyo (city center) and Ogouchi stations (rural area)

\begin{tabular}{|c|c|c|c|c|c|c|c|c|}
\hline \multirow[t]{2}{*}{$\begin{array}{l}\text { Name of } \\
\text { Observatory }\end{array}$} & \multicolumn{4}{|c|}{$\begin{array}{l}\text { Annual normals based on observed data from } \\
1981-2000\end{array}$} & \multicolumn{4}{|c|}{$\begin{array}{l}\text { Annual normals based on observed data from } \\
1991-2011\end{array}$} \\
\hline & $\begin{array}{l}\text { Mean } \\
\text { temp. }\left({ }^{\circ} \mathrm{C}\right)\end{array}$ & $\begin{array}{l}\text { Daily max. } \\
\text { temp. }\left({ }^{\circ} \mathrm{C}\right)\end{array}$ & $\begin{array}{l}\text { Daily min. } \\
\text { temp. }\left({ }^{\circ} \mathrm{C}\right)\end{array}$ & $\begin{array}{l}\text { Mean preci. } \\
(\mathrm{mm})\end{array}$ & $\begin{array}{l}\text { Mean } \\
\text { temp. }\left({ }^{\circ} \mathrm{C}\right)\end{array}$ & $\begin{array}{l}\text { Daily max. } \\
\text { temp. }\left({ }^{\circ} \mathrm{C}\right)\end{array}$ & $\begin{array}{l}\text { Daily min. } \\
\text { temp. }\left({ }^{\circ} \mathrm{C}\right)\end{array}$ & $\begin{array}{l}\text { Mean preci. } \\
(\mathrm{mm})\end{array}$ \\
\hline Tokyo & 16.3 & 20.0 & 13.0 & 1528.8 & 16.5 & 20.2 & 13.2 & 1574.0 \\
\hline Ogouchi & 11.9 & 17.1 & 8.1 & 1623.5 & 12.2 & 17.0 & 8.5 & 1616.1 \\
\hline
\end{tabular}

Tokyo Station $\left(35^{\circ} 41.1^{\prime} \mathrm{N}, 139^{\circ} 45.6^{\prime} \mathrm{E}\right.$, elevation=6.1 $\left.\mathrm{m} \mathrm{AMSL}\right)$; Ogouchi Station $\left(35^{\circ} 47.5^{\prime} \mathrm{N}, 139^{\circ} 0.3^{\prime} \mathrm{E}\right.$, elevation $=530.0 \mathrm{~m}$ AMSL)

Japan Meteorological Agency 2012b 

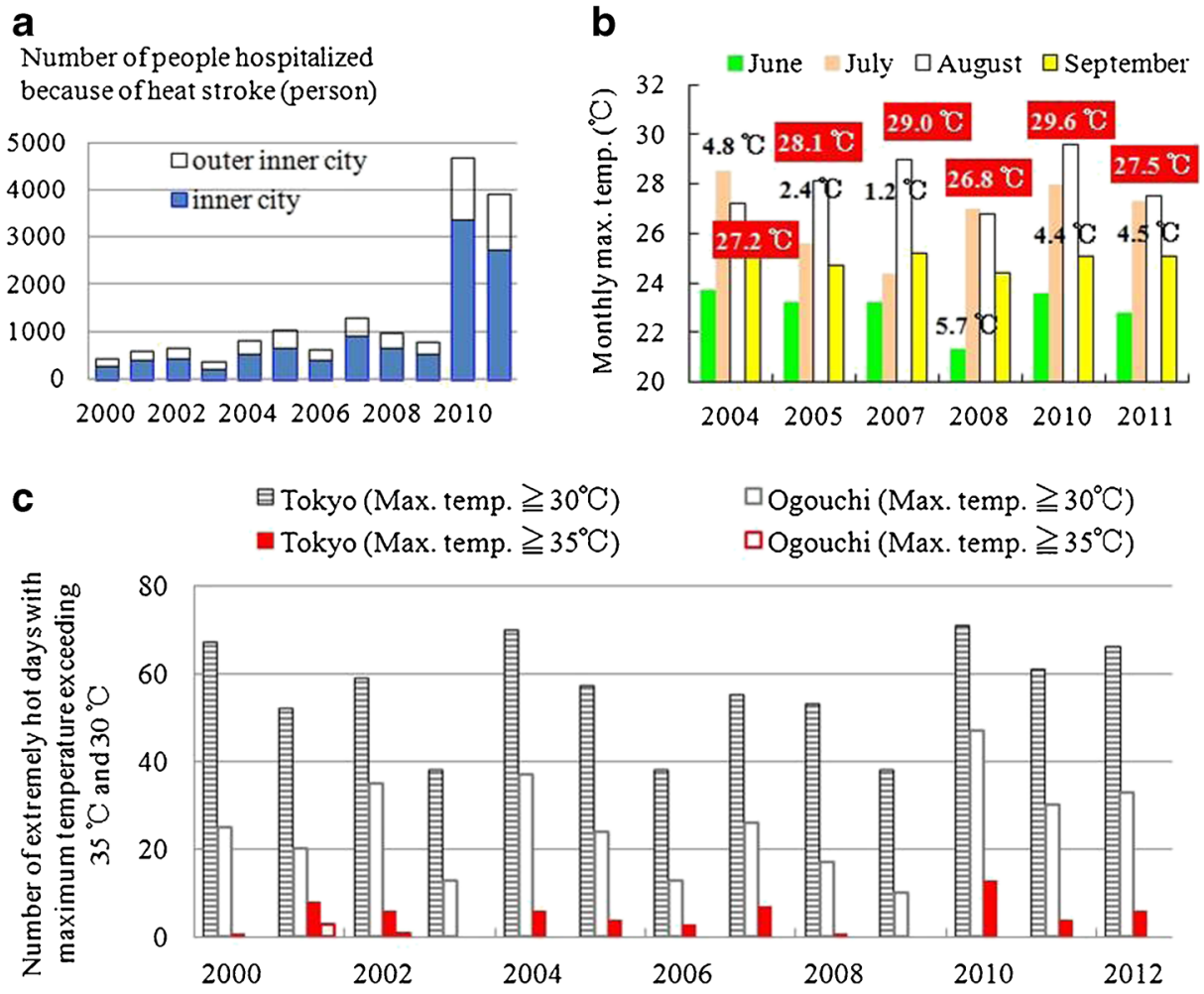

Fig. 5 Number of people hospitalized with heat stroke from 2000 to 2011 in Tokyo (a). Monthly maximum temperature in August and temperature difference between maximum temperature in June and July in 2004, 2005, 2007, 2008, 2010 and 2011 (800 or more hospitalized with heat stroke) (b) and number of extremely hot days with maximum temperature exceeding $30{ }^{\circ} \mathrm{C}$ and $35^{\circ} \mathrm{C}$ during $2000-2012$ based on the records from Tokyo (city center) and Ogouchi stations (rural area) (c). Black number in (b): temperature difference between maximum temperature in June and July; white number in (b): August maximum temperature. Data Source (a): Ministry of Health, Labour and Welfare, 2011. Data Source (b and c): Tokyo Fire Department 2012

and $1.2{ }^{\circ} \mathrm{C}$, respectively (Fig. 5b). In summer 2004 and 2008, August maximum temperatures were lower than $27.5{ }^{\circ} \mathrm{C}\left(27.2{ }^{\circ} \mathrm{C}\right.$ and $\left.26.8{ }^{\circ} \mathrm{C}\right)$, with highest temperature difference between monthly maximum temperature in June and July $\left(4.8{ }^{\circ} \mathrm{C}\right.$ and $5.7{ }^{\circ} \mathrm{C}$, respectively) (Fig. 5b), there were fewer people hospitalized with heat stroke in 2004 and 2008.

\subsection{GIS statistics modules}

A DMT with GIS modules can serve our purposes, since GIS can manage enormous amounts of data conveniently, cost effectively and quickly. GIS statistics of the DMT furnish a mapping approach which can be used to produce a regional development snapshot based on governmental statistical information.

Figure 6a shows the lowest population density is $0-10$ persons $/ \mathrm{km}^{2}$, which covers more than half the area as of 1 October 2010. The ratio of people aged 65 or older in Okutamamachi exceeds $25 \%$ (compared to the nationwide ratio of $23.01 \%$ as of 1 October 2010 ). There are two areas in Okutama-machi where this ratio is over $60 \%$ (Fig. 6b). 

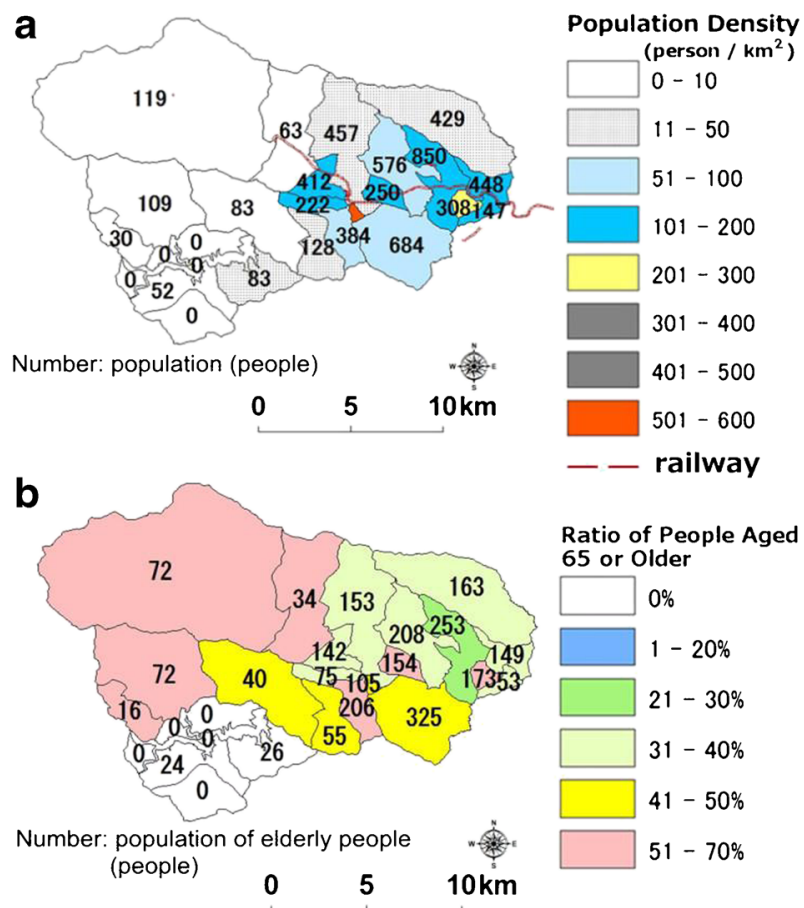

Fig. 6 Population density (a) and ratio of elderly people 65 years or older and population (b) predicted in Okutama-machi. Data Source: Ministry of International Affairs and Communications 2012

It seems obvious the Okutama-machi government is tasked with adaptation to climate change, along with addressing regional population issues and overcoming risks to the elderly. Hence, it is necessary to provide a common information base, including environmental and socioeconomic statistics and key climate change datasets to all levels of government, and allowing the merger of different indices and new datasets easily to facilitate policy-making as needed.

Moreover, GIS statistics modules can provide information related to regional public infrastructure, e.g., hospitals and public transport information, as well as demonstrate the importance of such information at a geographic scale. Statistical mapping results can display the main regional issues in Okutama-machi and outline the crises faced by local governors. The primary concern is the continuous decline in population (Fig. 3a). The arrival of a "super-aging" society and a decline in birthrate may progress to the point of dampening economic activity, increasing the load on the social security system, and sapping the vigor of society as a whole. Second, even if the local government is well prepared for a super-aging society, it is unclear if it will be possible to sustain adequate levels of medical care and public welfare in Okutama-machi, given its transportation difficulties. Third, the Tokyo Climate Change Strategy and Tokyo Metropolitan Environmental Master Plan (Tokyo Metropolitan Government 2010) outlines specific policy directions, which represent a dramatic departure from the past and progress toward achievement of an announced target for the metropolitan area. However, concerns have been raised about whether the information and climate change report are effective for policymaking regarding responses to potential consequences of climate change in unpopulated mountain areas. GIS statistics modules present sufficient visual evidence to enable local government leaders to directly reflect local needs in their policymaking decisions. 
3.2 Climate change indices (1979-2003, 2015-2039, and 2075-2099)

A suite of climate change indices derived from daily temperature and precipitation data, including projected climate data, were computed and analyzed. To obtain accurate and detailed temperature and precipitation information on a daily time scale, all observed data were from an array of JMA surface observation networks. These networks are composed of automatic observation equipment collectively known as the Automated Meteorological Data Acquisition System (AMeDAS). All observational data are transmitted to JMA's data base (Japan Meteorological Agency 2012b).

Projected climate data are based on the NHRCM- $5 \mathrm{~km}$ mesh regional climate model, with the SRES-A1B scenario. Sasaki et al. (2011), who developed the NHRCM-5 km, estimated its output in long-term climate projections and analyzed uncertainty based on model expert judgment. The bias of modeled annual mean temperature is $-0.3{ }^{\circ} \mathrm{C}$, and root mean square (RMS) errors are $0.7^{\circ} \mathrm{C}$. However, summer season output is almost the same as AMeDAS observations, except in mountainous areas (Sasaki et al. 2011).

The climate informatics module consists of the spatial distribution of projected climatic indices and their change, using daily, monthly and annual weather data (focus on temperature and precipitation in summertime) from three study periods (1979-2003, 2015-2039 and 20752099). The DMT creates the downscaled dataset over a simulation area of $120 \mathrm{~km} \times 60 \mathrm{~km}$, and displays the simulation results on the same GIS domain. Figure 7 illustrates mean temperature changes in the months of July to October over Tokyo in the near future (2015-2039) and future (2075-2099) periods. Because the time of NHRCM-5 km output is corrected from Coordinated Universal Time (UTC) to Japan time, there is less hourly data from 0000 to 0900 on 1 June, so data from 1 June are not used in the calculations. Simulation results from the GIS mapping tool indicate that summer temperatures in metropolitan Tokyo will increase by more than $2.5^{\circ} \mathrm{C}$ in the future period, and more than $0.5^{\circ} \mathrm{C}$ in the near-future period.

Downscaled NHRCM-5 km output provides changes in July to October monthly mean temperature, along with percent changes in monthly precipitation for those months, during the near-future and future periods at Okutama-machi. Figure 8 shows August monthly mean temperature will increase more than $0.7-0.9^{\circ} \mathrm{C}$, and monthly precipitation by $50 \%$ in the near-future period. For the future period, August monthly mean temperature will increase more than $2.8-2.9{ }^{\circ} \mathrm{C}$, and monthly precipitation by $25-41 \%$. The mean temperature increase at Okutama-machi is the greatest of any area in Tokyo during both periods.

Sasaki et al. (2011) showed that NHRCM-5 km output in the summer season is nearly the same as AMeDAS observations, except in mountainous areas. Because Okutama-machi is such a mountainous zone with a rough landscape, detailed comparisons between NHRCM$5 \mathrm{~km}$ output and observations over the last 25 years (1979-2003) are made based on daily mean surface air temperature from Ogouchi station. Figure 9 illustrates the cumulative relative frequency of NHRCM-5 km daily temperature in July, August, September and October during 1979-2003 (775 samples in July, August and October; 750 samples in September). The model ensemble mean (Fig. 9) shows qualitative agreement of daily mean temperature at the same elevation from July to October.

Allan and Soden (2008) found the observed amplification of rainfall extremes to be larger than that projected by models, and noted that projections of future changes of such extremes in response to anthropogenic global warming may be underestimated. Here, to estimate monthly NHRCM-5 km output for July to October mean precipitation, we selected

Fig. 7 Monthly mean temperature distribution in July, August, September and October for the present period (a), monthly mean temperature change in those months in near-future period and future period (b) based on simulation (present period: 1979-2003; near-future period: 2015-2039; future period: 2075-2099) 
a

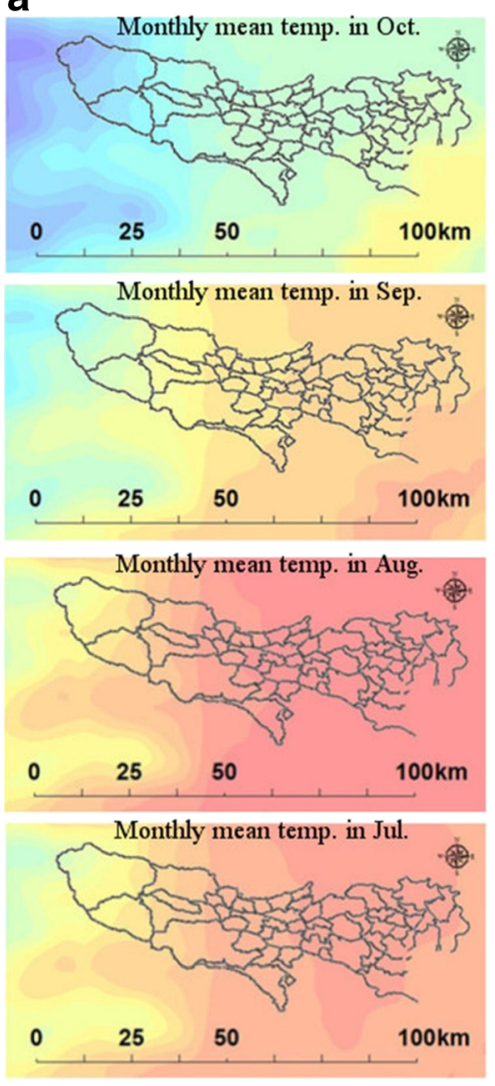

\begin{tabular}{|c|}
\hline $7.4-8.0^{\circ} \mathrm{C}$ \\
\hline $8.1-9.0^{\circ} \mathrm{C}$ \\
\hline $9.1-10.0^{\circ} \mathrm{C}$ \\
\hline $10.1-11.0^{\circ} \mathrm{C}$ \\
\hline $11.1-12.0^{\circ} \mathrm{C}$ \\
\hline $12.1-13.0^{\circ} \mathrm{C}$ \\
\hline $13.1-14.0^{\circ} \mathrm{C}$ \\
\hline $14.1-15.0^{\circ} \mathrm{C}$ \\
\hline $15.1-16.0^{\circ} \mathrm{C}$ \\
\hline $16.1-17.0^{\circ} \mathrm{C}$ \\
\hline $17.1-18.0^{\circ} \mathrm{C}$ \\
\hline $18.1-19.0^{\circ} \mathrm{C}$ \\
\hline $19.1-20.0^{\circ} \mathrm{C}$ \\
\hline $20.1-21.0^{\circ} \mathrm{C}$ \\
\hline $21.1-22.0^{\circ} \mathrm{C}$ \\
\hline $22.1-23.0^{\circ} \mathrm{C}$ \\
\hline $23.1-24.0^{\circ} \mathrm{C}$ \\
\hline $24.1-25.0^{\circ} \mathrm{C}$ \\
\hline $25.1-26.0^{\circ} \mathrm{C}$ \\
\hline $26.1-27.0^{\circ} \mathrm{C}$ \\
\hline
\end{tabular}

b Near-future period (2015-2039)
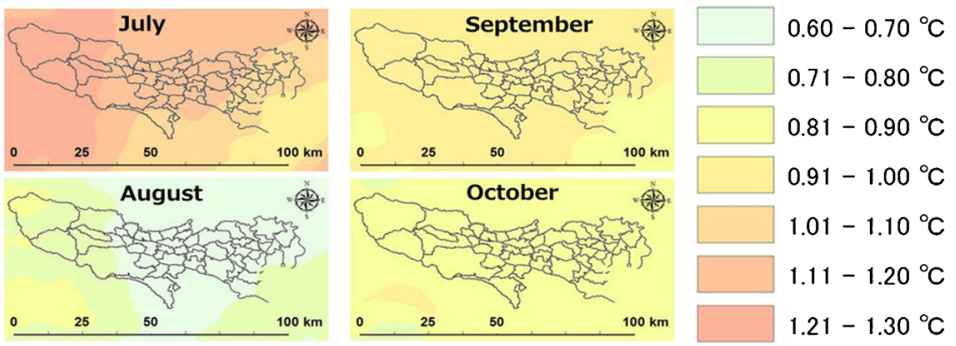

Future period (2075-2099)
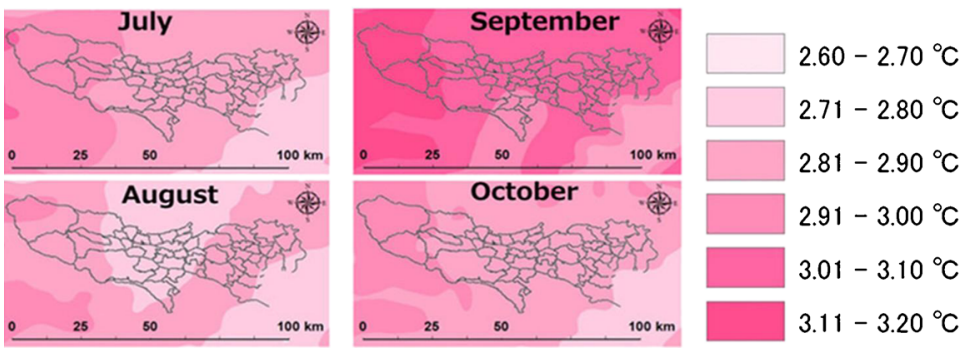

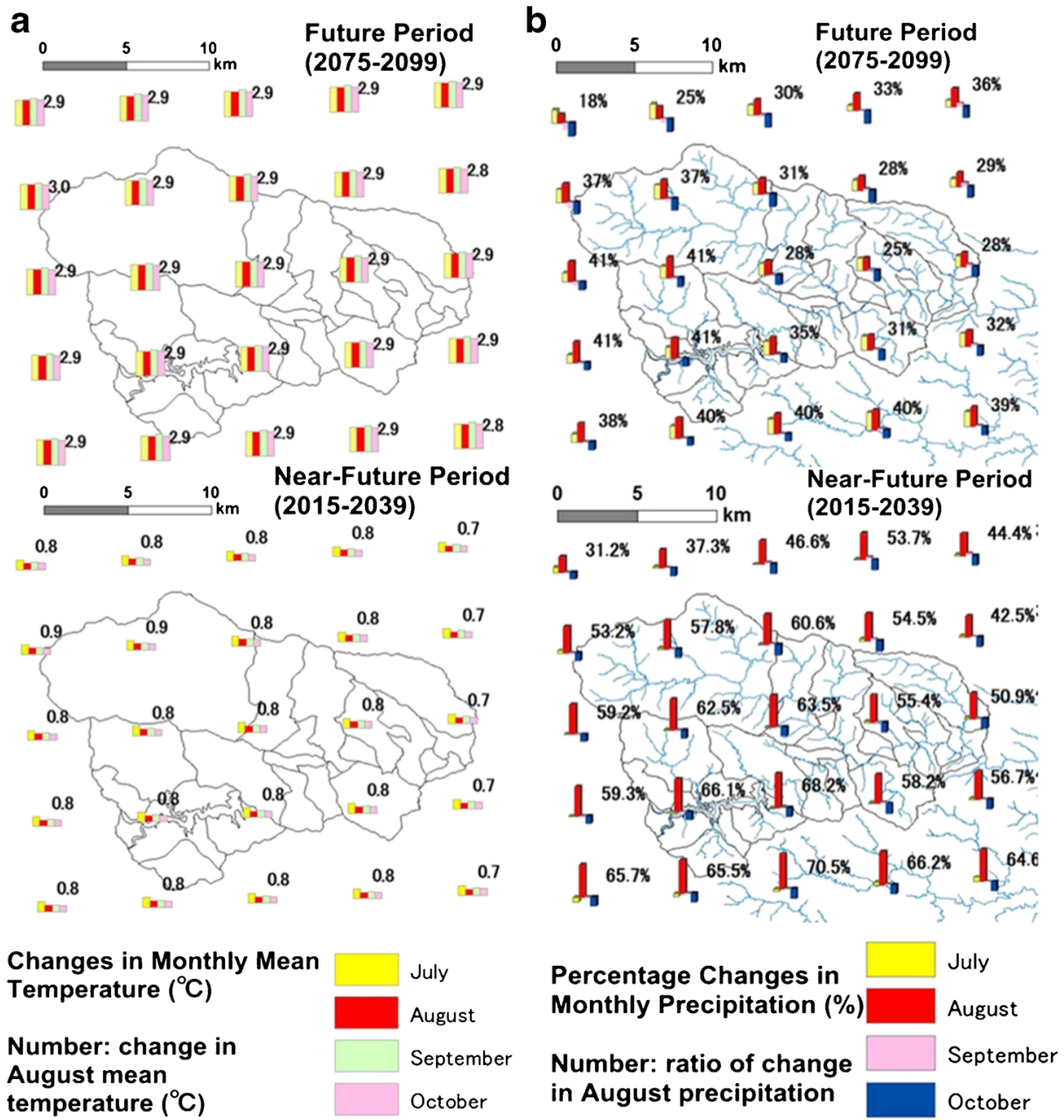

Fig. 8 Changes in July, August, September and October monthly mean temperature and percentage changes in monthly precipitation for those months at Okutama-machi, during near-future (2015-2039) and future (2075-2099) periods from NHRCM-5 km output. Numbers indicate change in August temperature (a), and ratio of change in August precipitation (b)

meteorological data from five meteorological stations in mountainous areas (Fig. 10b (2), (3), (4), (5) and (6): indicate the five meteorological stations in mountainous areas) covering Okutama-machi. Figure 10a reveals a large difference in performance around the five stations. The NHRCM-5 km mean precipitation was lower than observations in August, and higher than those in July. One reason for this variation seems that the model can reproduce the rainy season, known as Tsuyu in Japan, which will tend to arrive in Tokyo later in the season in the future than it does now (now, the rainy season in Tokyo begins in June; however, in the future, it will begin in July), because the subtropical high pressure around Japan becomes more active in the model than the observation. The NHRCM-5 km mean precipitation was higher than observations in July and lower than observations in August.

Unfortunately, there is little convincing information regarding this performance. As Sasaki et al. (2011) explained, the NHRCM can reproduce intense precipitation (more than 

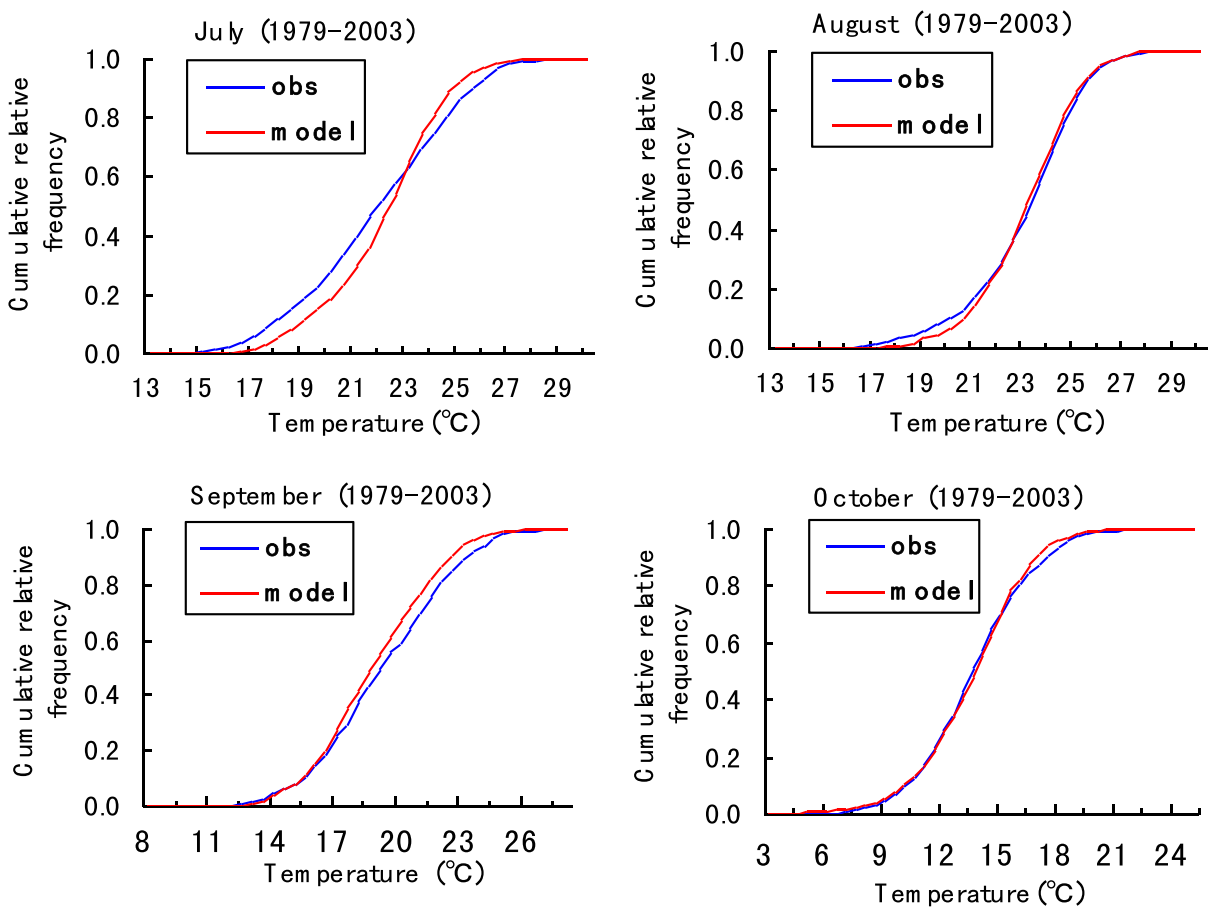

Fig. 9 Comparisons between observations (blue lines) and NHRCM-5 km output (red lines) of cumulative relative frequency (y-axis scale) distributions of daily mean temperature during July, August, September and October 1979-2003. Observed data records are from Ogouchi Station $\left(35^{\circ} 47.5^{\prime} \mathrm{N}, 139^{\circ} 0.3^{\prime} \mathrm{E}\right.$, elevation $530.0 \mathrm{~m} \mathrm{AMSL}$ ). Number of samples in July, August and October: 31 daily data $\times 25$ years $=775$ samples. Number of samples in September: 30 daily data $\times 25$ years $=750$ samples

$80 \mathrm{~mm} \mathrm{hour}^{-1}$ ) more accurately than the MRI-AGCM3.2S model. A climate-informatics analysis for Okutama-machi indicates agreement for the simulations of September and October monthly precipitation (Fig. 10a). This means that the NHRCM-5 km reproduces the peak of precipitation in these months, because of favorable simulation of typhoon landfall frequency.

Recent climate model improvements have enhanced the ability to simulate many aspects of climate variability and extremes. However, systematic errors and limitations in accurately simulating regional climate conditions remain (Easterling et al. 2000). Sasaki et al. (2011) gave bias and RMS error of annual mean precipitation difference between NHRCM-5 km and observations at $-11 \mathrm{~mm}$ and $379 \mathrm{~mm}$, respectively. Similarly, Kanada et al. (2010) reported bias of 10-year mean regional maximum precipitation in summertime between NHRCM-5 km and observations at $9 \%$, and bias in the number of wet days from June to October was $12 \%$. To estimate NHRCM-5 km errors of simulated precipitation, RMS errors and bias of monthly precipitation differences were calculated. Observed data are available from five observation stations (Fig. 8b and 2). RMS errors and bias are defined by formulas (1) and (2):

$$
R M S=\sqrt{\frac{1}{N} \sum_{k=1}^{N}\left(\operatorname{Mod}_{k}-O b s_{k}\right)^{2}}
$$


a

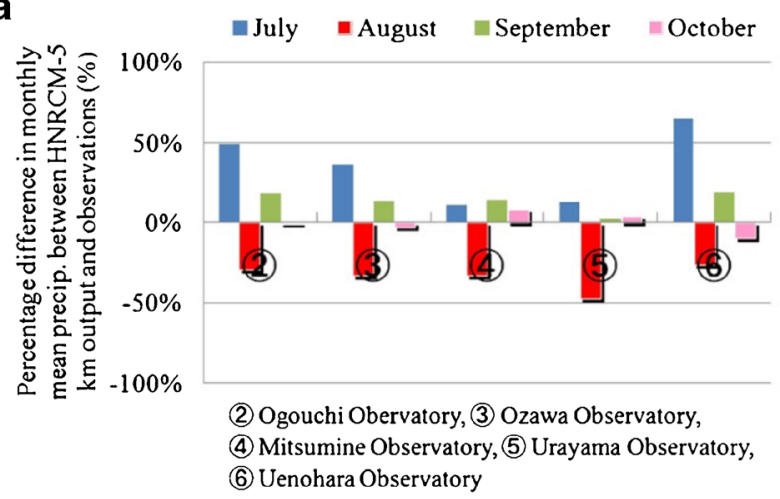

b
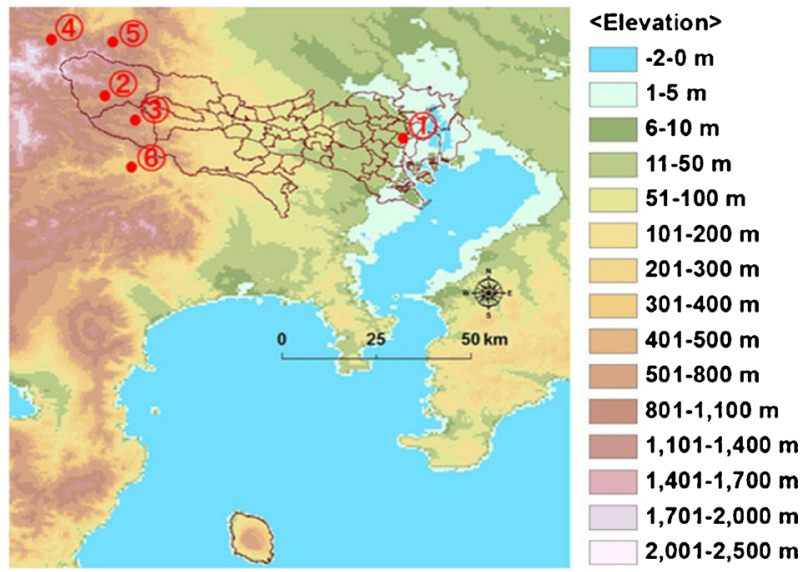

Fig. 10 Percentage difference in July, August, September and October monthly precipitation between HNRCM-5 km output and observations during 1979-2003 (a) and observation station location map with elevations (b). Observed data records are from (2) Ogouchi Station $\left(35^{\circ} 47.5^{\prime} \mathrm{N}, 139^{\circ} 0.3^{\prime} \mathrm{E}\right.$, elevation $530.0 \mathrm{~m}$ AMSL), (3) Ozawa Station ( $35^{\circ} 44.1^{\prime} \mathrm{N}, 139^{\circ} 7.4^{\prime} \mathrm{E}$, elevation $420.0 \mathrm{~m}$ AMSL), (4) Mitsumine Station $\left(35^{\circ} 55.6^{\prime}\right.$ $\mathrm{N}, 138^{\circ} 55.4^{\prime} \mathrm{E}$, elevation $\left.975.0 \mathrm{~m} \mathrm{AMSL}\right)$, (5) Urayama Station $\left(35^{\circ} 55.2^{\prime} \mathrm{N}, 139^{\circ} 4.2^{\prime} \mathrm{E}\right.$, elevation $400.0 \mathrm{~m}$ AMSL) and (6) Uenohara Station $\left(35^{\circ} 37.3^{\prime} \mathrm{N}, 139^{\circ} 6.8^{\prime} \mathrm{E}\right.$, elevation $251.0 \mathrm{~m}$ AMSL)

$$
\text { bias }=\frac{1}{N} \sum_{k=1}^{N}\left(\operatorname{Mod}_{k}-O b s_{k}\right)
$$

where $\mathrm{Mod}$ is model simulations and $\mathrm{Obs}$ is observations; $N$ is the number of data (number of observation stations $\times 25$ years $\times 4$ months $=500$ samples).

Data were analyzed for 25 years, from 1979 through 2003, and 4 months, from July through October. The RMS error of difference in July, August, September and October monthly precipitation between the model simulations and observations is $66.18 \mathrm{~mm}$, and the bias of difference is $-0.49 \mathrm{~mm}$. We also computed RMS errors and bias of percentage change for monthly precipitation of these months, which were $26.8 \%$ and $4.3 \%$, respectively. 


\subsection{Vulnerability assessment}

Vulnerability information is useful to moderate potential damages and take advantage of opportunities to adjust strategy as needed. Hallegatte and Corfee-Morlot (2011) stated understanding of vulnerability at a local scale can help national and subnational governments work closely with city authorities. If this is addressed, enabling national policy frameworks can help city authorities and other local decision-makers to execute locally-tailored, cost-effective and timely solutions. Here, the DMT is a basic tool for representing regional physical vulnerability to the direct impacts of local climate change.

Figures 11 and 12 give examples of vulnerability assessment in Okutama-machi. As seen in Fig. 7, mean temperatures increase in Okutama-machi faster than any area in Tokyo during both the near-future and future periods. However, Figs. 11 and $12 \mathrm{~b}$ show that the monthly average maximum temperature in Okutama-machi during the future period (20752099) will be less than $30{ }^{\circ} \mathrm{C}$. There is no significant change in the number of extremely hot days with maximum temperature exceeding $35{ }^{\circ} \mathrm{C}\left(0-0.92\right.$ day year ${ }^{-1}$ in that period; Fig. 12a, the above). These results caution that it is necessary to examine links between national and local climate policy response. The increase in August average maximum temperature during the future period is $2.7-2.9{ }^{\circ} \mathrm{C}$. Thus, it appears that one legitimate policy decision, as an example of design and delivery of a climate policy solution by local government, is the construction of a medical facility or healthcare center in Tozura for the aged (Fig. 3b). These firsthand analyses clarify high-priority issues and provide critical input to planning for climate change.

Figure $8 \mathrm{~b}$ illustrates the drainage network in Okutama-machi and percent changes of monthly precipitation from NHRCM-5 km, during the near-future (2015-2039) and future periods (2075-2099). In the near future, August monthly precipitation will increase by $50 \%$ (Fig. 8b). First-priority specific adaptation measures should be implemented to limit flood risks. The RMS error of percentage change for July to October monthly precipitation between model simulations and observations is $26.8 \%$, and the bias of percentage change is $4.3 \%$. The vulnerability assessment can be used to guide policymakers. For example, in the Nippara and Tozura area (Fig. 3b), aging population ratios exceed $50 \%$ and $60 \%$ as of 1 October 2010 (Fig. 6a), respectively. This means that regions vulnerable to climate change are also under pressure from forces such as changing population demographics. The potential vulnerability links between human lives and climate change become obvious. Sufficient information is available for policymaking about responses to potential climate change consequences, and this indicates an explicit need for initiatives by local governors to design adaptation strategies and build adaptive capacities.

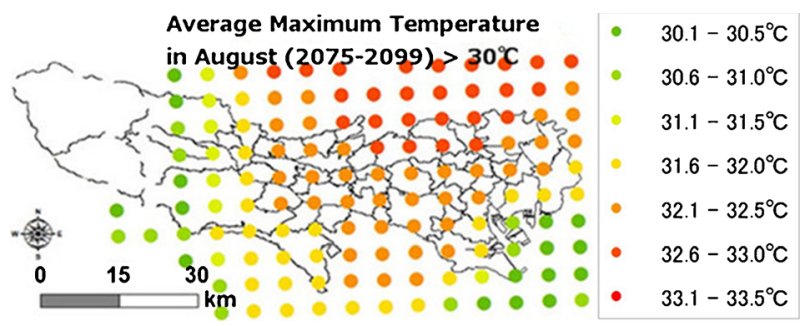

Fig. 11 Distribution of August average maximum temperature greater than or equal to $30{ }^{\circ} \mathrm{C}$ during $2075-2099$ 


\section{Results and discussion}

For decades, many international meteorological organizations have promoted advancement of an international cooperation framework to facilitate the availability of data, information, products and services in real- or near-real time, free to the research community. These organizations include the World Meteorological Organization (WMO), Global Climate Observing System (GCOS), Global Surface Network (GSN), European Climate Assessment (ECA) and daily Global Historical Climatology Network (GHCN Daily) (Alexander et al. 2006). In this paper, the ever expanding volumes of data $(5 \mathrm{~km}$ resolution) are easily and freely available to enable new scientific research by a GIS-based DMT. These data and the results that depend on them are useful to and understandable by a broad interdisciplinary audience, especially by the local policymakers. A similar approach can be achieved in the other areas/countries using observations and regional simulations for which the output can be downloaded freely.

The NHRCM-5 km output (only evaluates for Japan) is the most complete and current evaluation of projected climate change impacts on Japan. The pilot study leads to the following conclusions:

1) Using a GIS-based tool, the model promotes understanding of the most important consequences of climate change on local livelihoods. Figures 7, 8, 11 and 12 present simple mapping of local impact analysis of climate change in Okutama-machi. These results confirm the impacts of climate change are felt locally. Many attributes (Figs. 2, 3, 5 and 6) that determine human vulnerability and adaptive capacity are also local. Figures 3, 5 and 6 displays the main issues in the Okutama-machi region and the crisis faced by local government leaders. Knowledge of adaptation is limited within existing literature.

2) The DMT facilitates two-way exchange of local knowledge between researchers and decision makers. Non-expert governors will benefit from the tool by understanding the projections graphically; bias and RMS errors of simulation can be clearly determined. For example, as seen in Fig. 7, the mean temperature increase in Okutama-machi is the highest of any area in Tokyo during both near-future and future periods. However, Figs. 11 and $12 \mathrm{~b}$ show that the August monthly maximum temperature in Okutamamachi during the future period (2075-2099) will be less than $30^{\circ} \mathrm{C}$ based on the climate change projections. Figures 7 and 8 show the level of uncertainty, as given by the DMT.

3) The pilot study tested several functions of the DMT with GIS. The study outcome shows that the mapping tool can illustrate likely climate change during near-future (2015-2039) and future (2075-2099) periods, and can address different climate change adaptations needed on various time scales (Figs. 11 and 12). These outcomes and the basic tool can facilitate good decision making. Further, hazard-specific adaptive actions will have potential knock-on effects for generic governance systems. These can become equitable (more inclusive decision making) to avoid increased disparity and inequality.

4) The pilot study outcomes also suggest that online systems with services (datasets from GIS statistics are available for re-editing and visualization on web browsers) are central to adaptive capacity, because these make real-time information available to multiple users and encourage national and subnational governments to work closely with local authorities. This means that building bridging capital (connections between groups in society) is most important for local governments in unpopulated mountain regions, especially for marginal villages.

Currently, the need for managing climate vulnerabilities and for adaptation is widely understood. Questions about whether, how and when to adapt are often difficult to answer 


\section{a}
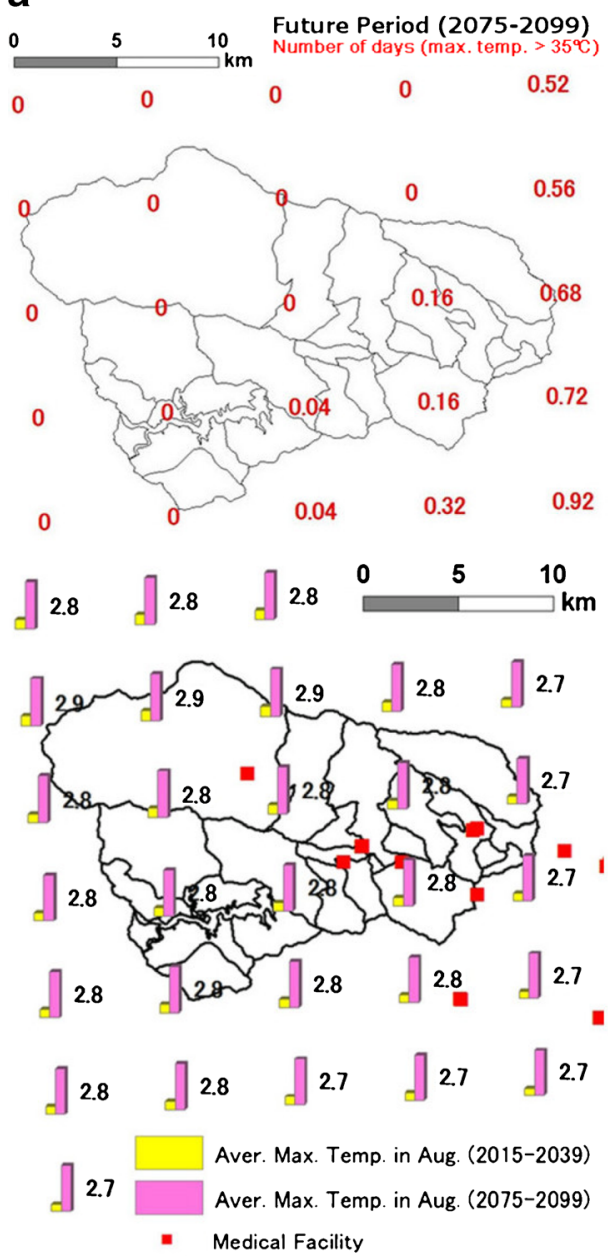

Number: Aver. Max. Temp. in Aug. (2075-2099)
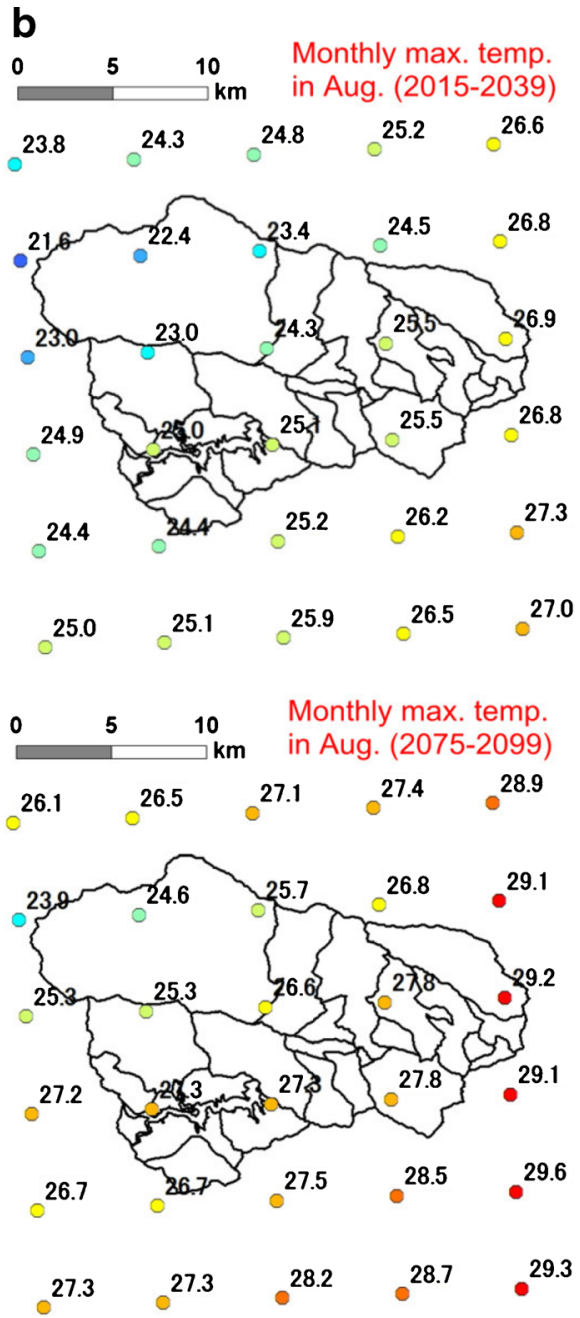

Fig. 12 Number of extremely hot days with maximum temperatures exceeding $35{ }^{\circ} \mathrm{C}$ and changes in average August maximum temperature during near-future and future periods (a); average maximum temperature in August during near-future and future periods based on simulation (b). Numbers in (a below) indicate the changes of monthly maximum temperature during near-future and future periods, and numbers (in b) indicate monthly maximum temperature in August during near-future and future periods (b)

for local governments. Our GIS-based approach for adaptation to regional climate change is valuable to decision-making by local governments. To effectively enhance DMT functions for adaptation planning on a local scale, there are three requirements for use of the basic tool.

First, is data quality and homogeneity. The pilot study indicates that these factors are particularly important for aggregating information and reducing uncertainty of projected future climate change. Each aggregation step can use different methods and adjust, so data quality is a relatively easy problem to address when compared with problems associated with non-homogeneous data. For instance, the single observation station in Okutama-machi covers $225.63 \mathrm{~km}^{2}$. Detailed temperature comparisons between NHRCM-5 km output and 

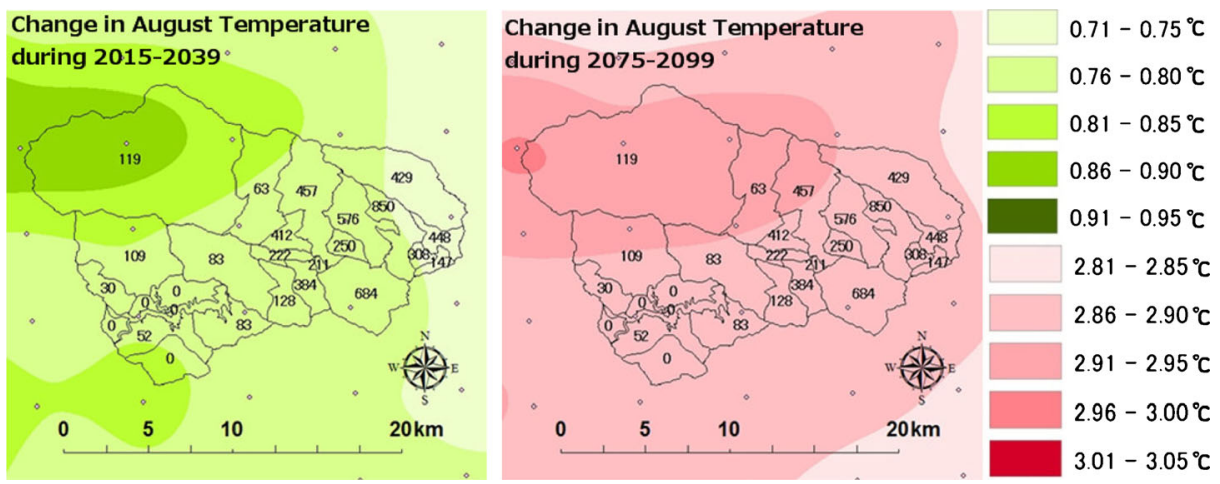

Fig. 13 Population distributions and detailed change of August temperatures during near-future and future periods in Okutama-machi. Numbers indicate population in each district

observations during the last 25 years (1979-2003) are difficult. If local observational data or a statistical dataset is not available, using the DMT is impossible. At the very least, it is necessary to facilitate internet access and create a basic dataset for adaptation to regional climate change and decision-making by a local government, especially in a depopulated community.

The second requirement is to minimize subjectivity and maximize generality. Villa and McLeod (2002) reported that it is risky and unwise to mix different-scale information in theoretical frameworks for obtaining an approximate vulnerability indicator. An important step is the scaling of indicators. Figure 13 illustrates population distributions and more detailed change of August temperatures, during the near-future and future periods in Okutama-machi. It is useful to calculate the degree of susceptibility and inability to cope with adverse effects of climate change (including climate variability and extremes), such as changes in groundwater content and spring water in mountain areas. Approximate quantification is necessary to aid consensus-building on adaptation to regional climate change among decision makers.

The third requirement is to adjust bias in projections, by developing new knowledge from science and practice. One method of increasing adaptive capacity is to consider climate impacts during regional development planning (IPCC 2007c). Bias can occur in subtle or unknown ways and its effect is not directly measurable, e.g., the bias of difference in July to October monthly precipitation between model simulations and observations in this pilot study was $-0.49 \mathrm{~mm}$. Therefore, evaluating existing bias is necessary when choosing socioeconomic development pathways.

Output from the NHRCM-5 km, following the SRES-A1B scenario is the highest resolution output available compared to other RCMs under CMIP5. It took about 2 years to run by Earths Simulator. After the Great East Japan Earthquake of 2011, power shortages awakened consumers to the importance of energy efficiency. Moreover, post-disaster power shortfalls have renewed interest in fossil fuels. Coal-fired power plants are now expected to play a greater role as a basic power source ("Japan To Smooth Path For Coal-Fired Plants," Nikkei English News, 2012). Japan's efforts to cut carbon dioxide emissions will be compromised with the new coal-fired power plant policy, and this appears to be heading in a considerably different direction from the pledge under the United Nations Framework Convention on Climate Change Kyoto Protocol. The need to consider the globally important issue of climate change risk thus becomes more acute for the government of Japan. There is only one selected alternative (scenario) which is connected to Japan's reality. 
The IPCC has commissioned and approved several sets of scenarios for climate research over the past two decades. However, the output from the NHRCM-5 km in this study only follows the SRES-A1B scenario. Our research group has been making a plan to help all local governments in Japan access, understand, and use these output (5 $\mathrm{km}$ resolution) to adapt to regional climate change using the DMT we illustrated. Our research group discussed and responded to this issue. The new reality and the urgency of regional adaptive action emphasize that scientists and other stakeholders are increasingly faced with questions about the suitability of high resolution data they use for various purposes. It seems a new regional climate research paradigm has come into existence: making sure those highest resolution data and the results are useful to, understandable by and meet the needs of a wide range of non-scientists users. This seems more important than simply providing several sets of scenarios as has occurred with traditional climate research, because as Jones (2000) recommended "both projection and scenario are used to describe possible future states, and two levels of uncertainty portrayal can be identified in the IPCC Working Group I with regard to estimates of climate change: scenarios and projections." Moreover, the projected range consists of a quantifiable range of uncertainty that encompasses the scenarios. Pittock and Jones (2000) also conclude that a high degree of uncertainty sometimes make scientific advice appear unhelpful to decision makers.

Open and free availability of model data, observations, and the software used for processing is crucial to all aspects of the new paradigm (Overpeck et al. 2011). The highest resolution NHRCM-5 $\mathrm{km}$ output provides a new approach that will lead to heightened collaboration between impacts, adaptation and vulnerability research, and climate and integrated assessment modeling. Our research group has been making a plan to help all local governments use GIS-based approaches to adapt to regional climate change in Japan using the DMT we illustrated. An all-inclusive adapted comparison analysis will improve the analysis of complex issues, such as the costs, benefits and risks of different policy choices and climate and socioeconomic futures. This perspective provides an overview of how the scenario is used in climate change research, and summarizes the new process and a framework for modeling in the next stages of scenario-based local research.

The DMT is a cost-effective, user-friendly mapping tool. We have been trying to adjust bias in climate projection. New downscaling methods and higher resolution simulations are needed. The " $\mathrm{K}$ computer" is now available to conduct high-resolution $(800 \mathrm{~m})$ simulations of atmospheric circulation, providing detailed projections of weather phenomena that elucidate localized effects, such as cloudbursts (RIKEN 2012). This improves the ability to downscale projections of global climate models to the local scale. Currently, out of 3,233 cities, towns, and villages in Japan, 1,208 are classified as depopulated areas, and they compose $48 \%$ of the total area of Japan (Ministry of International Affairs and Communications 2012). The DMT can facilitate closer working relationships between regional governments in these areas and the national government, which strengthens connections between local groups and decreases regional vulnerability to climate change.

Acknowledgments The authors would like to thank the Meteorological Research Institute, Japan Meteorological Agency for supporting this research. We also wish to thank Professor Akihiko Kondoh, Center for Environmental Remote Sensing, Chiba University, Mr. Ryunosuke Matsushita and Mr. Buhebaoyin (the latter two are graduate students in the Kondoh Laboratory of Chiba University) for their valuable comments on DMT development. Three anonymous reviewers greatly improved an earlier draft of this manuscript. This study is conducted under the Green Society ICT Life Infrastructure Project conducted by Keio University, supported by Strategic Funds for the Promotion of Science and Technology: Social System Reformation 
Program for Adaptation to Climate Change sponsored by the Ministry of Education, Culture, Sports, Science and Technology, Japan. The meteorological data has been prepared by KAKUSHIN program, supported by the Ministry of Education, Culture, Sports, Science, and Technology, Japan.

Open Access This article is distributed under the terms of the Creative Commons Attribution License which permits any use, distribution, and reproduction in any medium, provided the original author(s) and the source are credited.

\section{References}

Alexander LV, Zhang X, Peterson TC, Caesar J, Gleason B, Klein Tank AMG, Haylock M, Collins D, Trewin B, Rahimzadeh F, Tagipour A, Ambenje P, Rupa Kumar K, Revadekar J, Griffiths G (2006) Global observed changes in daily climate extremes of temperature and precipitation. J Geophys Res 111:D05109. doi:10.1029/2005JD006290

Allan RP, Soden BJ (2008) Atmospheric warming and the amplification of precipitation extremes. Science 321:481-1484. doi:10.1126/science.1160787

CMIP5 Coupled Model Intercomparison Project (2012) CMIP5 -Data Access- Availability. http://cmippcmdi.llnl.gov/cmip5/availability.html. Cited 1 December 2012

Corfee-Morlot J, Cochran I, Hallegatte S, Teasdale P-J (2011) Multilevel risk governance and urban adaptation policy. Clim Chang 104:169-197. doi:10.1007/s10584-010-9980-9

Davidian M, Louis TA (2012) Why statistics? Science 336:12. doi:10.1126/science.1218685

Duffy PB, Tebaldi C (2012) Increasing prevalence of extreme summer temperatures in the U.S. Clim Chang 111:487-495. doi:10.1007/s10584-012-0396-6

Easterling DR, Meehl GA, Parmesan C, Changnon SA, Karl TR, Mearns LO (2000) Climate extremes: observations, modeling, and impacts. Science 289:2068-2074. doi:10.1126/science.289.5487.2068

Elguindi N. and A. Grundstein (2012) An integrated approach to assessing 21st century climate change over the contiguous U.S. using the NARCCAP RCM output. Climatic Change (in press). doi: 10.1007/s10584-012-0552-z

Elguindi N, Rauscher SA, Giorgi F (2012) Historical and future changes in maximum and minimum temperature records over Europe. Clim Chang. doi:10.1007/s10584-012-0528-z

Hallegatte S, Corfee-Morlot J (2011) Understanding climate change impacts, vulnerability and adaptation at city scale: an introduction. Clim Chang 104:112. doi:10.1007/s10584-010-9981-8

Hayhoe K, Wake C, Anderson B, Liang X-Z, Maurer E, Zhu J, Bradbury J, DeGaetano A, Stoner AM, Wuebbles D (2008) Regional climate change projections for the Northeast USA. Mitig Adapt Strateg Glob Change 13:425-436. doi:10.1007/s11027-007-9133-2

IPCC Data Distribution Centre (2011) Constructing Sea-Level Scenarios for Impact and Adaptation Assessment of Coastal Areas: A Guidance Document: Version 1 (Proof) http://www.ipcc-data.org/docs/_Sea Level_Scenario_Guidance_Oct2011.pdf

IPCC Data Distribution Centre (2012a) Climate observations. http://www.ipcc-data.org/obs/index.html. Cited 26 September 2012

IPCC Data Distribution Centre (2012b) AR4 GCM Data. http://www.ipcc-data.org/gcm/monthly/SRES_AR4/ index.html. Cited 1 December 2012

IPCC Data Distribution Centre (2012c) Scenarios Process for AR5. http://sedac.ciesin.columbia.edu/ddc/ar5 scenario process/RCPs.html. Cited 1 December 2012

IPCC Fourth Assessment Report (2007a) In: Solomon S, Qin D, Manning M, Chen Z, Marquis M, Averyt KB, Tignor M, Miller HL (eds) The physical science basis. Contribution of working group I to the threeth assessment report of the intergovernmental panel on climate change, 2007. Summary for policymakers: direct observations of recent climate change. Cambridge University Press, Cambridge, http://www.ipcc.ch/publications_and_data/ ar4/wg1/en/spmsspm-direct-observations.html. Cited 26 September 2012

IPCC Fourth Assessment Report (2007b) In: Solomon S, Qin D, Manning M, Chen Z, Marquis M, Averyt KB, Tignor M, Miller HL (eds) The physical science basis. Contribution of working group I to the threeth assessment report of the intergovernmental panel on climate change, 2007. Chapter 10: Global climate projections: direct observations of recent climate change. Cambridge University Press, Cambridge, http://www.ipcc.ch/publications_and_data/ar4/wg1/en/ch10s10-es-8sea-level.html. Cited 1 December 2012

IPCC Fourth Assessment Report (2007c) In: Parry ML, Canziani OF, Palutikof JP, van der Linden PJ, Hanson $\mathrm{CE}$ (eds) Contribution of Working Group II to the threeth assessment report of the intergovernmental panel on climate change, 2007. Summary for policymakers: D. Current knowledge about responding to 
climate change. Cambridge University Press, Cambridge, http://ipcc.ch/publications_and_data/ar4/wg2/ en/spmsspm-d.html. Cited 26 September 2012

IPCC Third Assessment Report "Climate Change 2001" (Complete online versions: it was published to the web by GRID-Arendal in 2003) Working group II: impacts, adaptation and vulnerability. summary for policymakers: 2.4. Many human systems are sensitive to climate change, and some are vulnerable. Box SPM1. Climate change sensitivity, adaptive capacity, and vulnerability. http:/www.grida.no/publications/other/ ipcc_tar/. Cited 26 September 2012

Japan Meteorological Agency (2012a) Observations: surface observations. http://www.jma.go.jp/jma/en/ Activities/observations.html. Cited 26 September 2012

Japan Meteorological Agency (2012b) Metrological data. http://www.data.jma.go.jp/obd/stats/etrn/select/ prefecture00.php?prec_no=\&block_no=\&year $=\&$ month $=\&$ day $=\&$ view $=($ in Japanese $)$. Cited 26 September 2012

Jones RN (2000) Managing uncertainty in climate change projections - Issues for impact assessment An Editorial Comment. Clim Chang 45:403-419, http://stephenschneider.stanford.edu/PDF_Papers/Jones.pdf

Kanada S, Nakano AM, Kato K (2010) Climatological characteristics of daily precipitation over Japan in the Kakushin regional climate experiments using a non-hydrostatic 5-km-mesh model: comparison with an outer global 20-km-mesh atmospheric climate model. SOLA 6:117-120. doi:10.2151/sola.2010-030

Kitoh A, Ose T, Kurihara K, Kusunoki S, Sugi M, KAKUSHIN Team-3 Modeling Group (2009) Projection of changes in future weather extremes using super-high-resolution global and regional atmospheric models in the KAKUSHIN program: results of preliminary experiments. Hydrological Research Letters 3:49-53. doi:10.2151/jmsj.2012-B04

Kusaka H, Hara M, Tkane Y (2012) Urban climate projection by the WRF model at 3-km horizontal grid increment: dynamical downscaling and predicting heat stress in the 2070's August for Tokyo, Osaka, and Nagoya Metropolises. J Meteorol Soc Jpn 90B:47-63. doi:10.2151/jmsj.2012-B04

Lass W, Haas A, Hinkel J, Jaeger C (2011) Avoiding the avoidable: towards a European heat waves risk governance. Int J Disaster Risk Sci 2(1):1-14. doi:10.1007/s13753-011-0001-Z

Lemonsu A, Kounkou-Arnaud R, Desplat J, Salagnac J-L, Masson V (2013) Evolution of the Parisian urban climate under a global changing climate. Clim Chang 116:679-692. doi:10.1007/s10584-012-0521-6

Ministry of Health, Labour and Welfare (2011) Minister's Secretariat: Report of Statistics and Information Department. http://www.mhlw.go.jp/toukei/saikin/hw/jinkou/suii10/dl/s08.pdf. (in Japanese) Cited 25 September 2012

Ministry of International Affairs and Communications (2012) Statistics Bureau: Database of the national census. http://www.stat.go.jp/data/kokusei/2010/index.htm. (in Japanese) Cited 25 September 2012

Mizuta R, Yoshimura H, Murakami H, Matsueda M, Eudo H, Ose T, Kamiguchi K, Hosaka M, Sugi M, Yukimoto S, Kusunoki S, Kitoh A (2012) Climate simulations using MRI-AGCM 3.2 with 20-km grid. J Meteorol Soc Jpn 90A:233-258. doi:10.2151/jmsj.2012-A12

Murata A, Nakano M, Kanada S, Kurihara K, Sasaki H (2012) Summertime temperature extremes over Japan in the late 21 st century projected by a high-resolution regional climate model. J Meteorol Soc Jpn 90A:101-122. doi:10.2151/jmsj.2012-A05

Nakano M, Kato T, Hayashi S, Kanda S, Yamada Y, Kurihara K (2012) Notes and correspondence: development of a 5-km-mesh cloud-system-resolving regional climate model at the Meteorological Research Institute. J Meteorol Soc Jpn 90A:339-350. doi:10.2151/jmsj.2012-A19

Nikkei English News (2012) Japan to smooth path for coal-fired plants. September 25, 2012. http://e.nikkei.com/e/ fr/freetop.aspx. Cited 25 September 2012

Overpeck JT, Meehl GA, Bony S, Easterling DR (2011) Climate data challenges in the 21st century. Science 331:700-702. doi:10.1126/science.1197869

Patricola CM, Cook KH (2010) Northern African climate at the end of the twenty-first century: an integrated application of regional and global climate models. Clim Dyn 35:193-212. doi:10.1007/s00382-009-0623-7

Pittock AB, Jones RN (2000) Adaptation to what and why? Environ Monit Assess 61(1):9-35. doi:10.1023/ A: 1006393415542

RIKEN. 2012. RIKEN and Fujitsu Complete Operational Testing of the K computer. http://www.riken.go.jp/ engn/r-world/info/info/2012/120702/image/120702.pdf. Cited 25 September 2012

Sasaki H, Murata A, Hanafusa M, Ohizumi M, Kurihara K (2011) Reproducibility of present climate in a nonhydrostatic regional climate model nested within an atmosphere general circulation model. SOLA 7:173176. doi:10.2151/sola.2011-044

Sasaki H, Murata A, Hanafusa M, Ohizumi M, Kurihara K (2012) Projection of future climate change in a non-hydrostatic regional climate model nested within an atmospheric general circulation model. SOLA 8:53-56. doi:10.2151/sola.2012-014

Schröter D, Metzger MJ, Cramer W, Leemans R (2004) Vulnerability assessment. analyzing the humanenvironment system in the face of global environmental change. Environ Sci Sect Bull 2(2):11-17. doi:10.1016/S1462-9011(00)00102-7, http://www.cid.harvard.edu/events/papers/schroeter_proofs ESS04.pdf 
Tokyo Fire Department (2012) http://www.tfd.metro.tokyo.jp/hp-kouhouka/pdf/240517.pdf (in Japanese) cited 1 December 2012

Tokyo Metropolitan Government (2010) Tokyo climate change strategy: progress report and future vision (March 31, 2010). Environment of Tokyo: climate change. http://www.kankyo.metro.tokyo.jp/en/attachement/ Tokyo_climate_change_strategy_progress_report_03312010.pdf. Cited 25 September 2012

Villa F, McLEOD $\bar{H}$ (2002) Environmental vulnerability indicators for environmental planning and decisionmaking: guidelines and applications. Environ Manag 29(3):335-348. doi:10.1007/s00267-001-0030-2

WCRP Coupled Model Intercomparison Project-Phase 5: Special Issue of the CLIVAR Exchanges Newsletter (2011) http://www.clivar.org/sites/default/files/imported/publications/exchanges/Exchanges 56.pdf. Cited 1 December 2012

Willis JK, Church JA (2012) Regional sea-level projection. Science 336:550-551. doi:10.1126/science.1220366 